\title{
Plasma neurofilament light chain protein is not increased in treatment-resistant schizophrenia and first-degree relatives
}

Authors writing on behalf of the MiND Study Group:

\begin{tabular}{|c|c|c|c|c|}
\hline Name & $\begin{array}{l}\text { Affiliations } \\
\text { (separated by } \\
\text { semi colon) }\end{array}$ & Title & $\begin{array}{l}\text { Highest } \\
\text { qualification }\end{array}$ & Email \\
\hline $\begin{array}{l}\text { Dhamidhu } \\
\text { Eratne }\end{array}$ & $\begin{array}{l}\text { Neuropsychiatry, } \\
\text { Royal Melbourne } \\
\text { Hospital; Melbourne } \\
\text { Neuropsychiatry } \\
\text { Centre \& Department } \\
\text { of Psychiatry, } \\
\text { University of } \\
\text { Melbourne \& } \\
\text { Melbourne Health }\end{array}$ & $\mathrm{Dr}$ & $\begin{array}{l}\text { MBChB } \\
\text { FRANZCP }\end{array}$ & $\begin{array}{l}\text { deratne@unimelb.edu } \\
\text {.au }\end{array}$ \\
\hline $\begin{array}{l}\text { Shorena } \\
\text { Janelidze }\end{array}$ & $\begin{array}{l}\text { Department of } \\
\text { Clinical Sciences, } \\
\text { Clinical Memory } \\
\text { Research Unit, Faculty } \\
\text { of Medicine, Lund } \\
\text { University, } \\
\text { Lund/Malmö, Sweden }\end{array}$ & & PhD & $\begin{array}{l}\text { shorena.janelidze@m } \\
\text { ed.lu.se }\end{array}$ \\
\hline $\begin{array}{l}\text { Charles B } \\
\text { Malpas }\end{array}$ & $\begin{array}{l}\text { Clinical Outcomes } \\
\text { Research Unit } \\
\text { (CORe), Department } \\
\text { of Medicine, Royal } \\
\text { Melbourne Hospital, } \\
\text { The University of } \\
\text { Melbourne; } \\
\text { Department of } \\
\text { Neurology, Royal } \\
\text { Melbourne Hospital; } \\
\text { Melbourne School of } \\
\text { Psychological } \\
\text { Sciences, The } \\
\text { University of } \\
\text { Melbourne }\end{array}$ & $\mathrm{Dr}$ & PhD & $\begin{array}{l}\text { charles.malpas@unim } \\
\text { elb.edu.au }\end{array}$ \\
\hline Samantha Loi & $\begin{array}{l}\text { Neuropsychiatry, } \\
\text { Royal Melbourne } \\
\text { Hospital; Melbourne } \\
\text { Neuropsychiatry } \\
\text { Centre \& Department } \\
\text { of Psychiatry, } \\
\text { University of } \\
\text { Melbourne }\end{array}$ & $\mathrm{Dr}$ & $\begin{array}{l}\text { MBBS } \\
\text { FRANZCP } \\
\text { PhD }\end{array}$ & $\begin{array}{l}\text { Samantha.loi@unimel } \\
\text { b.edu.au }\end{array}$ \\
\hline $\begin{array}{l}\text { Mark } \\
\text { Walterfang }\end{array}$ & $\begin{array}{l}\text { Neuropsychiatry, } \\
\text { Royal Melbourne } \\
\text { Hospital; Melbourne } \\
\text { Neuropsychiatry } \\
\text { Centre \& Department } \\
\text { of Psychiatry, } \\
\text { University of } \\
\text { Melbourne; Florey } \\
\text { Institute of }\end{array}$ & Prof & $\begin{array}{l}\text { MBBS Hons } \\
\text { PhD } \\
\text { FRANZCP }\end{array}$ & $\begin{array}{l}\text { Mark.walterfang@mh. } \\
\text { org.au }\end{array}$ \\
\hline
\end{tabular}




\begin{tabular}{|c|c|c|c|c|}
\hline & $\begin{array}{l}\text { Neuroscience and } \\
\text { Mental Health }\end{array}$ & & & \\
\hline Antonia Merritt & $\begin{array}{l}\text { Melbourne } \\
\text { Neuropsychiatry } \\
\text { Centre \& Department } \\
\text { of Psychiatry, } \\
\text { University of } \\
\text { Melbourne \& } \\
\text { Melbourne Health }\end{array}$ & & & $\begin{array}{l}\text { antonia.merritt@unim } \\
\text { elb.edu.au }\end{array}$ \\
\hline Ibrahima Diouf & $\begin{array}{l}\text { Clinical Outcomes } \\
\text { Research Unit } \\
\text { (CORe), Department } \\
\text { of Medicine, Royal } \\
\text { Melbourne Hospital, } \\
\text { The University of } \\
\text { Melbourne; } \\
\text { Department of } \\
\text { Neurology, Royal } \\
\text { Melbourne Hospita }\end{array}$ & $\mathrm{Dr}$ & Phd & $\begin{array}{l}\text { Ibrahima.diouf@unim } \\
\text { elb.edu.au }\end{array}$ \\
\hline Kaj Blennow & $\begin{array}{l}\text { Clinical } \\
\text { Neurochemistry Lab, } \\
\text { Inst. of Neuroscience } \\
\text { and Physiology } \\
\text { University of } \\
\text { Gothenburg, } \\
\text { Sahlgrenska University } \\
\text { Hospital, Mölndal } \\
\text { Sweden }\end{array}$ & Prof & MD & $\begin{array}{l}\text { Kaj.blennow@neuro.g } \\
\text { u.se }\end{array}$ \\
\hline $\begin{array}{l}\text { Henrik } \\
\text { Zetterberg }\end{array}$ & $\begin{array}{l}{ }^{1} \text { Department of } \\
\text { Psychiatry and } \\
\text { Neurochemistry, } \\
\text { Institute of } \\
\text { Neuroscience and } \\
\text { Physiology, the } \\
\text { Sahlgrenska } \\
\text { Academy at the } \\
\text { University of } \\
\text { Gothenburg, Mölndal, } \\
\text { Sweden } \\
{ }^{2} \text { Clinical } \\
\text { Neurochemistry } \\
\text { Laboratory, } \\
\text { Sahlgrenska } \\
\text { University Hospital, } \\
\text { Mölndal, Sweden } \\
{ }^{3} \text { Department of } \\
\text { Neurodegenerative }\end{array}$ & Prof & $\mathrm{MD}, \mathrm{PhD}$ & $\begin{array}{l}\text { henrik.zetterberg@cli } \\
\text { nchem.gu.se }\end{array}$ \\
\hline
\end{tabular}




\begin{tabular}{|c|c|c|c|c|}
\hline & $\begin{array}{l}\text { Disease, UCL } \\
\text { Institute of Neurology, } \\
\text { Queen Square, } \\
\text { London, UK } \\
{ }^{4} \text { UK Dementia } \\
\text { Research Institute at } \\
\text { UCL, London, UK } \\
{ }^{5} \text { Hong Kong Center } \\
\text { for } \\
\text { Neurodegenerative } \\
\text { Diseases, Hong } \\
\text { Kong, China }\end{array}$ & & & \\
\hline Brandon Cilia & $\begin{array}{l}\text { The University of } \\
\text { Melbourne }\end{array}$ & & & $\begin{array}{l}\text { bjcilia@student.unime } \\
\text { lb.edu.au }\end{array}$ \\
\hline $\begin{array}{l}\text { Cassandra } \\
\text { Wannan }\end{array}$ & $\begin{array}{l}\text { Melbourne } \\
\text { Neuropsychiatry } \\
\text { Centre \& Department } \\
\text { of Psychiatry, } \\
\text { University of } \\
\text { Melbourne \& } \\
\text { Melbourne Health }\end{array}$ & $\mathrm{Dr}$ & $\mathrm{PhD}$ & $\begin{array}{l}\text { wannanc@unimelb.ed } \\
\text { u.au }\end{array}$ \\
\hline $\begin{array}{l}\text { Chad } \\
\text { Bousman }\end{array}$ & $\begin{array}{l}\text { Departments of } \\
\text { Medical Genetics, } \\
\text { Psychiatry, and } \\
\text { Physiology \& } \\
\text { Pharmacology, } \\
\text { University of Calgary }\end{array}$ & $\begin{array}{l}\mathrm{A} / \mathrm{Pr} \\
\text { of }\end{array}$ & $\mathrm{PhD}$ & $\begin{array}{l}\text { chad.bousman@ucalg } \\
\text { ary.ca }\end{array}$ \\
\hline Ian Everall & $\begin{array}{l}\text { Institute of Psychiatry, } \\
\text { Psychology \& } \\
\text { Neuroscience, }\end{array}$ & Prof & DSc & ian.everall@kcl.ac.uk \\
\hline $\begin{array}{l}\text { Andrew } \\
\text { Zalesky }\end{array}$ & $\begin{array}{l}\text { Melbourne } \\
\text { Neuropsychiatry } \\
\text { Centre \& Department } \\
\text { of Psychiatry, } \\
\text { University of } \\
\text { Melbourne \& } \\
\text { Melbourne Health }\end{array}$ & $\begin{array}{l}\mathrm{A} / \mathrm{Pr} \\
\text { of }\end{array}$ & $\mathrm{PhD}$ & $\begin{array}{l}\text { azalesky@unimelb.ed } \\
\text { u.au }\end{array}$ \\
\hline $\begin{array}{l}\text { Mahesh } \\
\text { Jayaram }\end{array}$ & $\begin{array}{l}\text { Melbourne } \\
\text { Neuropsychiatry } \\
\text { Centre \& Department } \\
\text { of Psychiatry, } \\
\text { University of } \\
\text { Melbourne \& } \\
\text { Melbourne Health; } \\
\text { Mid West Area } \\
\text { Mental Health } \\
\text { Service, Melbourne } \\
\text { Health }\end{array}$ & $\begin{array}{l}\mathrm{A} / \mathrm{Pr} \\
\text { of }\end{array}$ & MB BS & $\begin{array}{l}\text { mahesh.jayaram@uni } \\
\text { melb.edu.au }\end{array}$ \\
\hline
\end{tabular}




\begin{tabular}{|c|c|c|c|c|}
\hline $\begin{array}{l}\text { Naveen } \\
\text { Thomas }\end{array}$ & $\begin{array}{l}\text { Melbourne } \\
\text { Neuropsychiatry } \\
\text { Centre \& Department } \\
\text { of Psychiatry, } \\
\text { University of } \\
\text { Melbourne \& } \\
\text { Melbourne Health; } \\
\text { Mid West Area } \\
\text { Mental Health } \\
\text { Service, Melbourne } \\
\text { Health }\end{array}$ & $\mathrm{Dr}$ & $\mathrm{MD}$ & $\begin{array}{l}\text { Naveen.Thomas@mh } \\
\text {.org.au }\end{array}$ \\
\hline $\begin{array}{l}\text { Samuel F } \\
\text { Berkovic, MD, } \\
\text { FRS }\end{array}$ & $\begin{array}{l}\text { Epilepsy Research } \\
\text { Centre, Department } \\
\text { of Medicine, Austin } \\
\text { Health, The } \\
\text { University of } \\
\text { Melbourne, } \\
\text { Heidelberg }\end{array}$ & $\begin{array}{l}\text { Profe } \\
\text { ssor }\end{array}$ & MD FRS & $\begin{array}{l}\text { s.berkovic@unimelb.e } \\
\text { du.au }\end{array}$ \\
\hline $\begin{array}{l}\text { Oskar } \\
\text { Hansson }\end{array}$ & $\begin{array}{l}\text { Department of } \\
\text { Clinical Sciences, } \\
\text { Clinical Memory } \\
\text { Research Unit, Faculty } \\
\text { of Medicine, Lund } \\
\text { University, } \\
\text { Lund/Malmö, Sweden }\end{array}$ & & & $\begin{array}{l}\text { oskar.hansson@med.I } \\
\text { u.se }\end{array}$ \\
\hline $\begin{array}{l}\text { Dennis } \\
\text { Velakoulis, } \\
\text { MD, DMedSci; }\end{array}$ & $\begin{array}{l}\text { Neuropsychiatry, } \\
\text { Royal Melbourne } \\
\text { Hospital; Melbourne } \\
\text { Neuropsychiatry } \\
\text { Centre \& Department } \\
\text { of Psychiatry, } \\
\text { University of } \\
\text { Melbourne \& } \\
\text { Melbourne Health }\end{array}$ & $\begin{array}{l}\text { Profe } \\
\text { ssor }\end{array}$ & $\begin{array}{l}\text { MBBS } \\
\text { DMedSci } \\
\text { FRANZCP }\end{array}$ & $\begin{array}{l}\text { Dennis.velakoulis@m } \\
\underline{\text { h.org.au }}\end{array}$ \\
\hline $\begin{array}{l}\text { Christos } \\
\text { Pantelis (joint } \\
\text { senior author) }\end{array}$ & $\begin{array}{l}\text { Melbourne } \\
\text { Neuropsychiatry } \\
\text { Centre \& Department } \\
\text { of Psychiatry, } \\
\text { University of } \\
\text { Melbourne \& } \\
\text { Melbourne Health; } \\
\text { Mid West Area } \\
\text { Mental Health } \\
\text { Service, Melbourne } \\
\text { Health }\end{array}$ & Prof & $\begin{array}{l}\text { MBBS } \\
\text { MD } \\
\text { Hon MD } \\
\text { (Athens) }\end{array}$ & $\begin{array}{l}\text { cpant@unimelb.edu.a } \\
\text { u }\end{array}$ \\
\hline $\begin{array}{l}\text { Alexander } \\
\text { Santillo (joint } \\
\text { senior author) }\end{array}$ & $\begin{array}{l}\text { Department of } \\
\text { Clinical Sciences, } \\
\text { Clinical Memory } \\
\text { Research Unit, Faculty } \\
\text { of Medicine, Lund } \\
\text { University, } \\
\text { Lund/Malmö, Sweden }\end{array}$ & $\begin{array}{l}\text { Asso } \\
\text { ciate } \\
\text { Profe } \\
\text { ssor }\end{array}$ & MD, PhD & $\begin{array}{l}\text { alexander.frizell_santil } \\
\text { lo@med.Iu.se }\end{array}$ \\
\hline
\end{tabular}




\section{On behalf of the MiND Study Group [Appendix 1]}

\section{Corresponding author:}

Dr Dhamidhu Eratne

BHB MBChB FRANZCP

Neuropsychiatry, Royal Melbourne Hospital, 300 Grattan St, Parkville VIC 3050,

Australia

deratne@unimelb.edu.au

Tel: +61 393428750

\section{Submission Type: Research}

\section{Keywords:}

Schizophrenia, treatment-resistant, biomarker, neurofilament, diagnosis

\section{ORCID iD}

Dhamidhu Eratne: https://orcid.org/0000-0002-3226-7645

\section{ACKNOWLEDGEMENTS AND FUNDING SOURCES}

The authors acknowledge the financial support of the CRC for Mental Health. The Cooperative Research Centre (CRC) programme is an Australian Government Initiative. The authors wish to acknowledge the CRC Scientific Advisory Committee, in addition to the contributions of study participants, clinicians at recruitment services, staff at the Murdoch Children's Research Institute, staff at the Australian Imaging, Biomarkers and Lifestyle Flagship Study of Aging, and research staff at the Melbourne Neuropsychiatry Centre, including coordinators Merritt, A., Phassouliotis, C., and research assistants, Burnside, A., Cross, H., Gale, S., and Tahtalian, S. Participants for this study were sourced, in part, through the Australian Schizophrenia Research Bank (ASRB), which is supported by the National Health and Medical Research Council of Australia (Enabling Grant N. 386500), the Pratt Foundation, Ramsay Health Care, the Viertel Charitable Foundation and the Schizophrenia Research Institute. We thank the Chief Investigators and ASRB Manager: Carr, V., Schall, U., Scott, R., Jablensky, A., Mowry, B., Michie, P., Catts, S., Henskens, F., Pantelis, C., Loughland, C. We acknowledge the help of Jason Bridge for ASRB database queries.

CP was supported by a National Health and Medical Research Council (NHMRC) Senior Principal Research Fellowship (1105825), an NHMRC L3 Investigator Grant (1196508). 
Funding to AS was provided by Swedish federal government under the ALF agreement, Lund University, the Fredrik and Ingrid Thuring, Ellen and Henrik Sjöbring and the Fromma Foundation for medical research.

$\mathrm{HZ}$ is a Wallenberg Scholar supported by grants from the Swedish Research Council (\#2018-02532), the European Research Council (\#681712), Swedish State Support for Clinical Research (\#ALFGBG-720931), the Alzheimer Drug Discovery Foundation (ADDF), USA (\#201809-2016862), the AD Strategic Fund and the Alzheimer's Association (\#ADSF-21-831376-C, \#ADSF-21-831381-C and \#ADSF-21-831377-C), the Olav Thon Foundation, the Erling-Persson Family Foundation, Stiftelsen för Gamla Tjänarinnor, Hjärnfonden, Sweden (\#FO2019-0228), the European Union's Horizon 2020 research and innovation programme under the Marie SkłodowskaCurie grant agreement No 860197 (MIRIADE), and the UK Dementia Research Institute at UCL.

This Study was also supported by: MACH MRFF RART 2.2; Psychiatry and Rehabilitation Division, Region Skåne, Sweden. The role of these funding sources was to support research study staff and biosample analyses.

The authors are grateful for assistance from Brett Trounson and Dr Christopher Fowler and the team at The Florey Oak St Biobank.

Finally, the authors would like to thank all the participants and their families.

The corresponding author had full access to all the data in the study and had final responsibility for the decision to submit for publication.

\section{DECLARATION OF INTERESTS AND FINANCIAL DISCLOSURES}

$\mathrm{KB}$ has served as a consultant, at advisory boards, or at data monitoring committees for Abcam, Axon, Biogen, JOMDD/Shimadzu. Julius Clinical, Lilly, MagQu, Novartis, Prothena, Roche Diagnostics, and Siemens Healthineers, and is a co-founder of Brain Biomarker Solutions in Gothenburg AB (BBS), which is a part of the GU Ventures Incubator Program (outside the work presented in this paper). $\mathrm{HZ}$ has served at scientific advisory boards for Alector, Eisai, Denali, Roche Diagnostics, Wave, Samumed, Siemens Healthineers, Pinteon Therapeutics, Nervgen, AZTherapies and CogRx, has given lectures in symposia sponsored by Cellectricon, Fujirebio, Alzecure and Biogen, and is a co-founder of Brain Biomarker Solutions in Gothenburg AB (BBS), which is a part of the GU Ventures Incubator Program (outside submitted work).

MW has served as a consultant, at advisory boards, or at data monitoring committees for Actelion, Biomarin, Shire, Orphan, Vtesse and Orphazyme, and has received research funding from Eli-Lilly, Bristol Myers-Squibb and Pfizer.

The remaining authors have nothing to disclose.

\section{Statistical Analysis conducted by:}


Statistical analysis conducted by Dr Dhamidhu Eratne, MD, Neuropsychiatry, Royal Melbourne Hospital, with assistance from Dr Charles Malpas, Dr Ibrahima Diouf, and Dr Cassie Wannan. 


\section{ABSTRACT}

\section{Objective}

Schizophrenia, a complex psychiatric disorder, is often associated with cognitive, neurological and neuroimaging abnormalities. The processes underlying these abnormalities, and whether a subset of people with schizophrenia have a neuroprogressive or neurodegenerative component to schizophrenia, remain largely unknown. Examining fluid biomarkers of diverse types of neuronal damage could increase our understanding of these processes, as well as potentially providing clinically useful biomarkers, for example with assisting with differentiation from progressive neurodegenerative disorders such as Alzheimer and frontotemporal dementias

\section{Methods}

This study measured plasma neurofilament light (NfL) using ultrasensitive Simoa technology, to investigate the degree of neuronal injury in a well characterised cohort of people with treatment-resistant schizophrenia (TRS) on clozapine $(n=82)$, compared to first-degree relatives (an at-risk group, $n=37$ ), people with schizophrenia not treated with clozapine (NON-CLOZ, n=13), and age and sex matched controls $(n=59)$.

\section{Results}

We found no differences in NfL levels between TRS (Mean NfL, M=6.3pg/mL, 95\%Cl:[5.5, 7.2]), first-degree relatives (siblings, $\mathrm{M}=6.7 \mathrm{pg} / \mathrm{mL}, 95 \% \mathrm{Cl}:[5.2,8.2]$; parents, $\mathrm{M}$ after adjusting for age $=6.7 \mathrm{pg} / \mathrm{mL}, 95 \% \mathrm{Cl}:[4.7,8.8])$, controls $(\mathrm{M}=5.8 \mathrm{pg} / \mathrm{mL}, 95 \% \mathrm{Cl}:[5.3,6.3])$, and NON-CLOZ (M=4.9pg/mL, 95\%Cl:[4.0, 5.8]). 
Exploratory, hypothesis-generating analyses found weak correlations in TRS, between NfL and clozapine levels (Spearman's $r=0.258,95 \% \mathrm{Cl}:[0.034,0.457]$ ), dyslipidaemia $(r=0.280,95 \% \mathrm{Cl}:[0.064,0.470])$, and a negative correlation with weight $(r=-0.305,95 \% \mathrm{Cl}:[-0.504,-0.076])$.

\section{Conclusions}

TRS does not appear to be associated with neuronal, particularly axonal degeneration. Further studies are warranted to investigate the utility of NfL to differentiate TRS from neurodegenerative disorders such as behavioural variant frontotemporal dementia, and to explore NfL in other stages of schizophrenia such as the prodome and first-episode. 


\section{INTRODUCTION}

2

3 Schizophrenia is a severe, complex psychiatric disorder, with a lifetime prevalence of

4 approximately $1 \%$, which causes significant functional and occupational impairment,

5 and reduced life expectancy of approximately 20 years (Kahn et al., 2015).

6 Symptoms are traditionally grouped into 'positive symptoms' (such as delusions and

7 hallucinations) and 'negative symptoms' (such as apathy and social withdrawal). A

8 proportion of patients have chronic, residual symptoms and impairment, including

9 cognitive symptoms, despite current best available pharmacological and non-

10 pharmacological interventions (Kahn et al., 2015; McCutcheon et al., 2020). While

11 current models of schizophrenia posit it as a neurodevelopmental disorder (Forsyth

12 and Lewis, 2017), there is evidence that some people with schizophrenia may have

13 a progressive neurodegenerative disorder (Blennow et al., 1996; Pantelis et al.,

14 2005; Rund, 2009).

16 Early descriptions of cognitive and functional decline in some people with

17 schizophrenia, such as Kraepelin's concept of dementia praecox, have been

followed by more recent studies which have raised the possibility of a

neuroprogressive or neurodegenerative component to schizophrenia, at least in a subset of patients (Kochunov and Hong, 2014; Velakoulis et al., 2009), consistent with evidence of progressive deterioration in some cognitive domains including associative memory (Wannan et al., 2018) and attentional set-shifting (Pantelis, Wood, et al., 2009). 
1 In addition to cognitive impairments, schizophrenia is associated with neurological

2 'soft signs' and neuroimaging abnormalities (Chan et al., 2010; Kahn et al., 2015).

3 There is evidence of abnormalities at first episode and in chronic schizophrenia, with

4 evidence of progressive reductions in whole brain, grey and white matter volume

5 and structure, and enlarged ventricles, with grey matter changes being most

6 apparent during the earliest stages of illness (Berger et al., 2017; Cropley et al.,

7 2017; Kelly et al., 2018; Pantelis et al., 2003; van Erp et al., 2018; Velakoulis et al.,

8 2006; Vita et al., 2019). Understanding these changes is complicated by potential

9 confounders, such as general medical and substance use co-morbid disorders, the

10 effects of pharmacological treatments of schizophrenia, the findings of 'accelerating

11 ageing' (Cropley et al., 2017), and the interaction between dynamic changes seen at

12 different stages of the illness and normal brain development (Pantelis et al., 2005;

13 Pantelis, Yücel, et al., 2009). There remains some debate whether neuronal injury or

14 neurodegeneration occurs in schizophrenia to explain some of the above

15 abnormalities (Rund, 2009), and the processes underlying the neurological and

16 neuroimaging findings are largely unknown. Thus, examining fluid biomarkers of

17 diverse types of neuronal damage could increase our understanding of these

processes as well as possibly providing clinically useful biomarkers, for example with assisting in the often challenging clinical distinction of schizophrenia and other psychiatric disorders, from neurodegenerative disorders such as behavioural variant

21 frontotemporal dementia (Chan et al., 2014; Ducharme et al., 2020; Eratne, Loi,

22 Walia, et al., 2020).

24 Neurofilament light chain protein $(\mathrm{NfL})$ is an essential component of the neuronal 25 cytoskeleton, critical for growth and stability of axons in particular (Yuan et al., 2017). 
1 Elevated levels in cerebrospinal fluid (CSF) and blood have been demonstrated in a

2 wide range of neurological and neurodegenerative conditions, with NfL functioning

3 as a biomarker to identify and grade neuroaxonal injury, as well as for staging,

4 prognosis and treatment response in many conditions (Ashton et al., 2021; Bridel et

5 al., 2019; Gaetani et al., 2019; Khalil et al., 2018). A recent study explored plasma

$6 \mathrm{NfL}$ in 42 people with schizophrenia (including nine on clozapine), and reported

7 slightly higher NfL levels in schizophrenia compared to controls, and higher levels in

8 clozapine-treated patients compared to controls (Rodrigues-Amorim et al., 2020).

9 This study did not use ultrasensitive technology however, unlike more recent plasma

$10 \mathrm{NfL}$ studies. Another recent study assessed serum NfL in 44 people with

11 schizophrenia (including nine on clozapine), finding no differences in levels when

12 compared to a reference (not matched) normal population, but observed a greater

13 proportion of people with levels above the 95th and 99th percentiles (Bavato et al.,

14 2021). Regarding other severe psychiatric disorders, Bavato et al found higher

15 serum NfL levels in people with major depressive disorder (MDD) compared to

16 reference values from a healthy norm population, and another study found elevated

17 levels in older women with major depressive disorders (Bavato et al., 2021;

18 Gudmundsson et al., 2010). Ashton et al found no difference between MDD and

19 controls (Ashton et al., 2021). Studies have found no change in NfL levels during

20 electroconvulsive therapy (Besse et al., 2020; Zachrisson et al., 2000). One study

21 found elevated CSF NfL levels in people with bipolar disorder, and levels were

22 associated with antipsychotic medication (Jakobsson et al., 2014). In our previous

23 study, we found mildly elevated CSF NfL levels in about two-thirds of people with

24 primary psychiatric disorders (including a group of individuals with schizophrenia

25 spectrum disorders), when compared to suggested age-specific cut-offs (Eratne, Loi, 
1 Walia, et al., 2020). This finding provided preliminary support for us to explore

2 plasma NfL in severe, chronic psychiatric disorders, such as treatment-resistant

3 schizophrenia, which although controversial, could be conceptualised as a

4 progressive disorder (Vita et al., 2019). To our knowledge, no studies have used

5 ultrasensitive technology to specifically examine plasma NfL concentrations in a

6 large group of well-characterised participants with schizophrenia, and, in particular,

7 in people with treatment-resistant schizophrenia.

8

9 The primary aim of this study was to compare plasma NfL levels in a large group of 10 people with TRS (defined as failing to respond to two or more adequate trials of 11 antipsychotics (Howes et al., 2017)), to healthy controls. Secondary aims were to 12 compare levels in TRS, unaffected siblings and parents, and a cohort of people with

13 schizophrenia that were not on clozapine. We hypothesised that people with TRS

14 would demonstrate elevated levels of NfL compared to controls. In addition, we

15 performed exploratory, hypothesis generating analyses for associations between NfL

16 levels and key demographic and clinical variables, in the TRS group. We broadly

17 hypothesised that higher NfL levels would be associated with age, as well as greater 18 illness severity and cognitive impairment.

20 METHODS

22 Participant recruitment and data

23 Samples and data were obtained from the Cooperative Research Centre (CRC)

24 Psychosis Study, which has been described previously (Bousman et al., 2019;

25 Mostaid et al., 2017). Briefly, the CRC Psychosis Study was a cross-sectional study 
1 that recruited people aged 18-65 from inpatient and outpatient services in

2 Melbourne, Australia, who were on clozapine and had a diagnosis of treatment-

3 resistant schizophrenia (TRS), between 2012-2017. In addition, a group of first-

4 degree relatives of the TRS group (siblings and parents) were recruited. Also

5 included were a group of people with schizophrenia who were not treated with

6 clozapine (NON-CLOZ), and a comparison group of unrelated, age, sex and

7 sociodemographic matched healthy controls recruited from the general community.

8 All participants were administered the Mini International Neuropsychiatric Interview

9 to confirm the diagnosis of schizophrenia and to rule out current or past psychiatric

10 illness in controls. The Positive and Negative Syndrome Scale (PANSS) was also

11 administered, and functioning was evaluated using the Social and Occupational

12 Functioning Assessment Scale (SOFAS). In addition, current IQ was measured

13 using the two-subtest short forms (vocabulary and matrix reasoning) of the WAIS-III

14 (Ryan and Lopez, 2001). Detailed demographic, medical and other information was 15 collected, as demonstrated in Table 1.

17 Sample analysis

18 Fasting blood samples were collected and plasma aliquots stored at -80 degrees

19 Celsius. Plasma NfL levels were measured using a Simoa NF-Light Advantage Kit

20 (SR-X), a digital immunoassay (mean limit of detection $=0.0552 \mathrm{pg} / \mathrm{mL}$ ), according

21 to the manufacturer's recommendations (Quanterix Corporation, Billerica, MA USA).

22 All samples were diluted 1:4 in a sample diluent and analyzed in duplicates. The

23 average intra-plate coefficient of variability (CV) was $4.97 \%$. Four quality control

24 (QC) samples were included in every plate. The average inter-plate CV of the QC 
1 samples was $6.59 \%$. NfL measurements were performed by a technician blinded to

2 the clinical data.

4 All the participants provided written informed consent, after oral and written

5 information was provided. The CRC psychosis study protocol, and this study, were

6 approved by the Melbourne Health Human Research Ethics Committee (MHREC IDs

$7 \quad 2012.069$ and 2020.142)

8

9 Statistical Analysis

10 All statistical analyses were performed using IBM SPSS 27 and R. General linear

11 models (GLM) were estimated to examine the relationships between NfL, groups,

12 and clinical variables. Given the established relationship between age and NfL levels

13 (Gaetani et al., 2019; Khalil et al., 2018), age at blood sample was included as a

14 covariate where appropriate. A number of variables displayed non-gaussian

15 distributions. As such, robust inference methods were used for all analyses. These

16 robust statistical methods were selected because they mitigate the effects of

17 distributional violations, including the presence of outliers. Bias-corrected and

18 accelerated $(\mathrm{BCa})$ confidence intervals were computed for all GLMs via

19 nonparametric bootstrapping, with 1000 replicates used. Statistical significance was

20 defined as any confidence interval not capturing the null-hypothesis value (at the

$2195 \%$ level). Spearman correlation coefficients were computed for exploratory,

22 hypothesis generating analyses. Sensitivity analyses were performed, including and

23 excluding outliers, and analyses were performed with both log10 transformed NfL

24 levels and untransformed levels, and any impacts of these sensitivity analyses

25 reported. 
2 Follow-up Bayesian t-tests were used to investigate whether negative group

3 differences for the primary aim could be explained by low statistical power (Rouder

4 et al., 2009). Hypothesis testing was performed by computation of the Bayes factor

5 for the alternative hypothesis $\left(\mathrm{BF}_{10}\right)$, which represents the ratio of evidence for the

6 alternative hypothesis over the null hypothesis. Following Kass and Raftery (1995),

7 we considered BF10 > 3.2 as an approximate lower bound of evidence for the

8 alternative hypothesis. Conversely, $\mathrm{BF}_{10}<1 / 3.2$ was taken as a convenient

9 boundary for evidence supporting the null hypothesis. $\mathrm{BF}_{10}$ values between

10 approximately $1 / 3.2$ and 3.2 were considered insensitive to either hypothesis given

11 the evidence (Kass and Raftery, 1995).

12

13 In addition, further sensitivity analyses using Welch's t-test, Levene's test of

14 homogeneity of variances, and generalised additive models for location, scale, and

15 shape (GAMLSS), were performed to explore the presence in groups and impact of

16 heterogeneity of variance and unequal sample sizes on the results.

\section{RESULTS}

20 Study cohort details

22 A total of 191 participants from the CRC Psychosis Study Treatment Resistant

23 Schizophrenia biobank had plasma samples available for NfL analysis and were

24 included. Eighty-two participants had treatment-resistant schizophrenia (TRS).

25 Thirty-seven participants were first-degree family members (compromising 21 
1 siblings and 16 parents), related to 33 TRS participants. A group of 13 people with

2 schizophrenia not treated with clozapine was available for comparison (NON-CLOZ),

3 as well as 59 control participants, who were age and sex matched to the TRS group.

4 TRS, NON-CLOZ, siblings, and controls did not differ in age (Table 1). As expected,

5 the TRS group had higher frequencies of cardiovascular and general medical

6 comorbidities, and poorer performance on the WASI_IQ, compared to controls and

7 siblings. Both the TRS and NON-CLOZ groups had long duration of illness of 17.6

8 and 17.9 years, respectively. $29 \%$ in the TRS group had had electroconvulsive

9 therapy previously, compared to $0 \%$ in the NON-CLOZ group. Both patient groups

10 demonstrated deficits on the SOFAS measure of functioning, which are scored out of

11 100, with higher scores indicating better functioning. TRS and NON-CLOZ were not

12 different with regard to age at onset, duration of illness, PANSS positive scores. Full

13 demographic and illness variables are detailed in Table 1.

$\mathrm{NfL}$ levels in treatment-resistant schizophrenia, controls and other groups

17 NfL levels are described in Table 2 and Figure 1. Two outliers were noted, one in the control group (45-year-old male, NfL 46.2pg/mL, z-score=6.96) and another in the parent group (67-year-old father, NfL 119.8pg/mL, z-score=3.71). Neither of these outliers had any known pre-analytical factors that would have falsely elevated levels,

21 and both were healthy with no clinical symptoms. These outlier samples were analysed 3 times, and levels did not differ by more than $10 \%$. These outliers, more

23 than five to ten times the mean in their respective groups, although not impacting the

24 final statistical significance, did influence the unadjusted and adjusted means.

25 Therefore, results with these extreme outliers included and excluded, are presented. 
2 The mean NfL level in the TRS group was $6.3 \mathrm{pg} / \mathrm{mL}(95 \% \mathrm{Cl}:[5.5,7.2])$. Levels in the

3 TRS group were not different to controls $(5.8 \mathrm{pg} / \mathrm{mL} 95 \% \mathrm{Cl}:[5.3,6.3]$, mean

4 difference (Mdiff)=0.4pg/mL, 95\%Cl:[-0.6, 1.4], and including outlier: $\mathrm{Mdiff}=0.3 \mathrm{pg} / \mathrm{mL}$

$595 \% \mathrm{Cl}:[-1.3,1.9])$. A Bayesian t-test was performed to determine if this negative

6 result was related to an underpowered study. The Bayes factor for the alternative

7 hypothesis $\left(\mathrm{BF}_{10}\right)$ as 0.14 , which provided evidence for the null hypothesis and

8 suggested that the negative finding was not due to the study being underpowered.

10 Levels in NON-CLOZ and siblings were 4.9pg/mL 95\%Cl:[4.0, 5.8], and 6.7pg/mL

$1195 \% \mathrm{Cl}:[5.2,8.2]$, respectively. There were no statistical differences between TRS,

12 siblings, NON-CLOZ and controls (Mdiff 95\% confidence intervals all included 0,

13 whether including or excluding the control group outlier).

15 Percentile distributions between TRS, NON-CLOZ, siblings, compared to age16 matched controls (Supplementary Table 1), showed an increased proportion of TRS 17 and siblings participants with levels above the $90^{\text {th }}$ percentile (Fisher Exact Test $p=$ 180.039 and $p<0.001$, respectively), but not above $95^{\text {th }}$ and $98^{\text {th }}$ percentiles, unlike 19 Bavato and colleagues (Bavato et al., 2021).

21 After adjusting for the higher age in parents, there were no differences in NfL levels compared to the other groups. After adjusting for age, NfL levels estimated marginal

23 mean in parents, excluding outlier was $6.7 \mathrm{pg} / \mathrm{mL}(95 \% \mathrm{Cl}:[4.7,8.8])$, including parent

24 outlier was 13.3pg/mL (95\%Cl:[5.3, 25.8]); Mdiff 95\% confidence intervals with all 25 other groups included 0 , including and excluding the outlier. 


\section{Additional sensitivity analyses}

3 We repeated the primary analyses using Welch's t-test, and we also computed

4 Levene's test of homogeneity of variances to directly investigate the presence of

5 unequal variances. Finally, we re-estimated the general linear models (GLMs) using

6 a robust sandwich estimator, which allowed for the inclusion of the age term in the

7 model. These results are shown in Supplementary Table 2. Levene's test suggested

8 statistically significant heterogeneity of variance across the TRS vs control, sibling vs

9 control, and parent vs control comparisons. Both Student's and Welch"s t-tests,

10 however, resulted in the same decision regarding the null hypothesis (all $p>0.05$ ).

11 Estimation of the group term using the robust estimator also produced non-

12 significant results. The parent vs control comparison produced statistically significant

13 results for both Student's and Welch's t-tests, however this did not survive the GLM

14 once age was included as a covariate. A similar pattern was observed for the NON-

15 CLOZ vs TRS comparison: Welch's t-test was marginally significant, but this

16 difference did not survive adjustment for age in the GLM.

18 Finally, following Bavato and colleagues (Bavato et al., 2021), we computed z scores

19 from age-adjusted percentiles in the control group using generalised additive models

20 for location, scale, and shape (GAMLSS), implemented in R.(Bavato et al., 2021) We

21 then used single sample t-tests to test the hypothesis that the mean $z$ score was 0

22 (i.e., equal to the mean of the control group). These results were not statistically

23 significant for the TRS $(M=-0.31, S D=2.00, p=0.17)$, NON-CLOZ $(M=-0.49, S D$

$24=1.08, p=0.13)$, and sibling $(M=-0.04, S D=1.65, p=0.91)$ group. There was

25 evidence for elevated NFL levels in the parent group $(M=0.89, S D=0.96, p=$ 
$10.003)$, which once again was most probably driven by the expected younger age in

2 the control group (range $=22-62$ ) compared to the parent group (range $=54-77$ )

3

4 Taken together, these sensitivity analyses suggested that heterogeneity of variances

5 does not explain the lack of statistically significant group differences.

6

7

8

9

10

11 Spearman correlations were performed to explore associations between NfL levels

Associations between NfL and demographic and illness variables in treatmentresistant schizophrenia

and the demographic and illness variables listed in Table 1, in the TRS group.

As expected, the strongest correlation was seen between NfL levels and age at sample (Spearman's $r=0.683,95 \% \mathrm{Cl}:[0.546,0.785]$. An association was seen between duration of illness and NfL levels (Spearman's $r=0.467,95 \% \mathrm{Cl}:[0.267$, 0.629]). However, as expected, longer durations of illness were strongy associated with being older (Spearman's $r=0.774,95 \% \mathrm{Cl}:[0.664,0.849])$. There was some collinearity between age at sample and duration of illness (tolerance $=0.401$, variance inflation factore $(\mathrm{VIF})=2.496)$, but these were just within acceptable limits. A regression model for $\mathrm{NfL}$, age at sample, and duration of illness ( $R$ square $=0.585$, adjust $\mathrm{R}$ square $=0.325, \mathrm{~F}$ change $19.513, p<0.001)$, demonstrated that age was a significant predictor (coefficient $0.266,95 \% \mathrm{Cl}:[0.143,0.388], p<0.001$ ), but duration of illness was not (coefficient $-0.034,95 \% \mathrm{Cl}:[-0.172,0.105], p=0.632)$. This appears to show that age is driving the model, but not duration of illness. Despite these 
1 findings, it is difficult to disentangle the causal effects of duration of illness entirely.

2 Weak correlations were seen with clozapine levels $(n=80$, Spearman's $r=0.258$,

$395 \% \mathrm{Cl}:[0.034,0.457])$ and dyslipidaemia (Spearman's $r=0.280,95 \% \mathrm{Cl}:[0.064$,

$4 \quad 0.470]$ ). In addition, we identified a negative correlation between $\mathrm{NfL}$ and weight in

5 the TRS group (Spearman's $r=-0.305,95 \% \mathrm{Cl}:[-0.504,-0.076])$. A slightly weaker

6 correlation was seen between NfL and BMI (Spearman's $r=-0.264,95 \% \mathrm{Cl}:[-0.48$, -

7 .019]), but not with height. Further information can be found in the Supplementary

8 Table 3, and Supplementary Figures 1-5. In order to determine the influence of these

9 variables on the overall results for the primary aim, post-hoc comparisons of NfL

10 levels between TRS and other groups, adjusting for age, and in addition weight, BMI,

11 dyslipidaemia, duration of illness, and clozapine levels, were performed. Including

12 these additional covariates did not change the overall results described in the

13 previous section.

\section{DISCUSSION}

16 While neurofilament light has been explored in a broad range of neurological and

17 neurodegenerative disorders, few studies have examined NfL levels in primary

18 psychiatric disorders. This study explored plasma NfL levels in the largest group, to

19 date, of well-characterised patients on clozapine with treatment-resistant

20 schizophrenia (TRS). In addition, this was the first study to explore NfL in siblings of

21 people with TRS, who constitute a schizophrenia at-risk cohort. We did not find

22 increased NfL levels in TRS, a cohort that represents severe disease, with long

23 duration of illness and significant residual positive, negative and significant cognitive

24 symptoms. Our result was likely not due to an underpowered study. 
1 Our previous studies compared CSF NfL levels in a smaller group of schizophrenia

2 spectrum disorders and other primary psychiatric disorders, to neurological and

3 neurodegenerative disorders. We found no statistically significant differences

4 between different primary psychiatric disorders and controls, but lower levels in

5 primary psychiatric disorders compared with neurological and neurodegenerative

6 disorders (Eratne, Loi, Li, et al., 2020; Eratne, Loi, Walia, et al., 2020). Several

7 studies have included or explored NfL levels in patients with schizophrenia, many

8 comparing them to neurodegenerative disorders such as frontotemporal dementia.

9 (Al Shweiki et al., 2019; Bavato et al., 2021; Katisko et al., 2020; Rodrigues-Amorim

10 et al., 2020; Zerr et al., 2018) However, these studies had smaller numbers, less

11 comprehensively characterised patients, mixed psychiatric cohorts rather than

12 specifically exploring schizophrenia, and did not include many people with severe

13 and treatment-resistant schizophrenia, and people on clozapine.

15 There are several possible reasons to explain why we did not find differences in NfL

16 levels between this group of people with TRS, and controls. First, although NfL exists

17 in both axons and dendrites, it is much more abundant in axons. Our findings suggest that schizophrenia may not be associated with axonal injury or

19 degeneration, even in a group of people with severe, chronic illness. Our findings are

20 contradictory to the neuroimaging findings of white matter alterations in

21 schizophrenia (Kelly et al., 2018). What these alterations represent

22 histopathologically is not established but may be secondary to cortical (such as

23 synaptic/dendritic) processes, or myelinative pathology without severe axonal

24 pathology. Given such diffusion tensor imaging abnormalities generally show a

25 relationship to NfL (Spotorno et al., 2020), our findings could add weight to the notion 
1 that the main pathological processes in schizophrenia, rather than axonal, are

2 synaptic and/or dendritic (Forsyth and Lewis, 2017). This is also in agreement with

3 studies showing synaptic loss in specific brain regions in schizophrenia (Blennow et

4 al., 1996). Second, NfL levels may change dynamically in schizophrenia (for

5 example, there may be increased rate of change or elevated levels in NfL at the first

6 episode/onset of illness, or with acute episodes, that then return to normal with

7 treatment or a more chronic course of illness), not dissimilar to the dynamic changes

8 seen in relapsing remitting multiple sclerosis (Kuhle et al., 2019). Therefore while our

9 findings improve our understanding of neuroaxonal involvement in TRS, suggesting

10 against the presence of accelerated neurodegeneration in chronic treatment-

11 resistant schizophrenia on clozapine, further research is required to address the

12 possibility of neuroxonal involvement in other disease stages: in younger patients

13 earlier in the disease course, at high risk for psychosis, with first episode psychosis,

14 pre- and post-treatment, and during acute episodes. It is also possible that NfL acts

15 as a marker of treatment response to clozapine, again not dissimilar to multiple

16 sclerosis (Kuhle et al., 2019), therefore studies investigating NfL in treatment-

17 resistant schizophrenia pre- and post-clozapine, and in untreated psychosis, would

18 be important. Our NON-CLOZ group was small, and of similar age and illness

19 duration to the TRS group, thus limiting any interpretations that could be made from

20 this group. Third, given that NfL levels reflect the severity, intensity and rapidity of

21 progression of neuronal injury and degeneration, it may be that NfL levels are either

22 not sensitive to a slower rate of neuronal degeneration in schizophrenia or that

23 neuroimaging abnormalities may not relate primarily to axonal injury, of which NfL is

24 primarily a marker. Fourth, there is significant heterogeneity in clinically diagnosed

25 schizophrenia and TRS (Potkin et al., 2020), and likely differences in underlying 
1 genetic, environmental and other aetiological and pathophysiological mechanisms.

2 Studies that focused on specific subgroups of patients with schizophrenia with

3 neuroimaging abnormalities compared to those without, or with specific and clearly

4 defined endophenotypes, may demonstrate differences in NfL levels. Fifth, while

5 cerebrospinal fluid and blood NfL levels have been shown to correlate strongly in a

6 range of conditions (Khalil et al., 2018), this may not be the case in schizophrenia.

7 We did not have access to CSF data in this population, but future studies should

8 examine this issue. The TRS group had a relatively high proportion of head injuries

9 and neurological disorder diagnoses, and electroconvulsive therapy (ECT), reflective

10 of the severity of their condition. While ECT has not been shown to elevate NfL

11 levels (Besse et al., 2020), neurological diagnoses and a history of head trauma

12 (especially recent) could have been expected to result in elevated NfL levels in the

13 TRS group (Khalil et al., 2018), and thus a potential confounder. However, despite

14 this, we did not find elevated NfL in TRS and we found no association between these

15 factors and levels. Although we found some percentile distribution differences,

16 limited interpretations can be made given the sample sizes, and sensitivity analyses

17 taken together did not explain the lack of statistical differences between groups.

18 Additional limitations of our study include the cross-sectional nature of the study, the

19 lack of adequate information on a broader range of clinical variables (such as

20 duration of clozapine treatment, treatment setting, number of episodes, treatment in

21 the NON-CLOZ group, which would be important areas for future research), and the

22 lack of serial NfL levels and follow up clinical information, limiting interpretations on

23 longitudinal trajectories of brain pathology and longer term outcomes. 
1 Even though our study did not include patients with neurodegenerative disorders, our

2 findings of similar NfL levels in TRS and age-matched controls fill an important gap

3 in the literature, and suggest that schizophrenia is not associated with the degree of

4 axonal injury seen in neurodegenerative disorders such as Alzheimer disease and

5 behavioural variant frontotemporal dementia, where significantly elevated levels are

6 commonly observed (compared to controls and non-neurodegenerative disorders)

7 (Al Shweiki et al., 2019; Bridel et al., 2019; Eratne, Loi, Li, et al., 2020; Gaetani et al.,

8 2019; Katisko et al., 2020; Khalil et al., 2018). Our results add further weight to the

9 potential diagnostic and clinical utility of $\mathrm{NfL}$ for psychiatrists and other specialists in

10 clinical practice, in differentiating people with established schizophrenia (even

11 treatment-resistant or poor outcome), from progressive neurodegenerative disorders

12 such as behavioural variant frontotemporal dementia, an often-challenging clinical

13 distinction (Chan et al., 2014; Ducharme et al., 2020; Eratne, Loi, Li, et al., 2020;

14 Eratne, Loi, Walia, et al., 2020).

16 Our exploratory, hypothesis-generating analyses identified some correlations that

17 may warrant further investigation. The correlation observed between plasma NfL and

18 clozapine levels was weak, and furthermore, there were no differences in NfL levels

19 between the clozapine-treated TRS group, and the non-clozapine treated group

20 (although the latter group was small). Whether this finding signifies some degree of

21 neuronal injury related to clozapine, or a reflection of more severe illnesses that

22 required higher doses of clozapine, requires further study. Our finding of an inverse

23 relationship between weight and NfL levels has been observed in a few other studies

24 (Barro et al., 2020; Manouchehrinia et al., 2020; Nilsson et al., 2019). Given findings

25 of other non-neuronal factors that can influence plasma NfL levels, such as renal 
1 function (Akamine et al., 2020), weight may have to be considered and adjusted for,

2 for precise modelling and interpretation NfL levels, and further research is required.

3

4 In conclusion, our study did not find evidence for differences in plasma NfL levels in

5 a large, well-characterised cohort of people with treatment-resistant schizophrenia

6 on clozapine, compared with unaffected siblings (an elevated risk group) and

7 parents, controls, and a group of people with non-clozapine-treated schizophrenia.

8 Studies exploring NfL and neuroimaging correlates in TRS are underway, and further

9 study is warranted in other stages of the illness, such as during the high-risk and

10 prodrome period, first episode, and during acute episodes.

11 


\section{REFERENCES}

Akamine S, Marutani N, Kanayama D, et al. (2020) Renal function is associated with blood neurofilament light chain level in older adults. Scientific Reports 10(1): 20350. DOI: 10.1038/s41598-020-76990-7.

Al Shweiki MR, Steinacker P, Oeckl P, et al. (2019) Neurofilament light chain as a blood biomarker to differentiate psychiatric disorders from behavioural variant frontotemporal dementia. Journal of Psychiatric Research 113(February). Elsevier: 137-140. DOI: 10.1016/j.jpsychires.2019.03.019.

Ashton NJ, Janelidze S, Al Khleifat A, et al. (2021) A multicentre validation study of the diagnostic value of plasma neurofilament light. Nature Communications 12(1): 3400. DOI: 10.1038/s41467-021-23620-z.

Barro C, Chitnis T and Weiner HL (2020) Blood neurofilament light: a critical review of its application to neurologic disease. Annals of Clinical and Translational Neurology 7(12): 2508-2523. DOI: 10.1002/acn3.51234.

Bavato F, Cathomas F, Klaus F, et al. (2021) Altered neuroaxonal integrity in schizophrenia and major depressive disorder assessed with neurofilament light chain in serum. Journal of Psychiatric Research 140: 141-148. DOI: 10.1016/j.jpsychires.2021.05.072.

Berger GE, Bartholomeusz CF, Wood SJ, et al. (2017) Ventricular volumes across stages of schizophrenia and other psychoses. Australian \& New Zealand Journal of Psychiatry 51(10): 1041-1051. DOI: 10.1177/0004867417715914.

Besse M, Belz M, Folsche T, et al. (2020) Serum neurofilament light chain (NFL) remains unchanged during electroconvulsive therapy. The World Journal of Biological Psychiatry 21(2): 148-154. DOI: 10.1080/15622975.2019.1702717.

Blennow K, Davidsson P, Gottfries CG, et al. (1996) Synaptic degeneration in thalamus in schizophrenia. Lancet (London, England) 348(9028): 692-693. DOI: 10.1016/S01406736(05)65124-0.

Bousman CA, Luza S, Mancuso SG, et al. (2019) Elevated ubiquitinated proteins in brain and blood of individuals with schizophrenia. Scientific Reports 9(1): 2307. DOI: 10.1038/s41598-019-38490-1.

Bridel C, van Wieringen WN, Zetterberg H, et al. (2019) Diagnostic Value of Cerebrospinal Fluid Neurofilament Light Protein in Neurology: A Systematic Review and Metaanalysis. JAMA neurology 76(9): 1035-1048. 
Chan HM, Stolwyk R, Kelso W, et al. (2014) Comparing neurocognition in severe chronic schizophrenia and frontotemporal dementia. Australian and New Zealand Journal of Psychiatry 48(9): 828-837. DOI: 10.1177/0004867414529477.

Chan RCK, Xu T, Heinrichs RW, et al. (2010) Neurological Soft Signs in Schizophrenia: A Metaanalysis. Schizophrenia Bulletin 36(6): 1089-1104. DOI: 10.1093/schbul/sbp011.

Cropley VL, Klauser P, Lenroot RK, et al. (2017) Accelerated Gray and White Matter Deterioration With Age in Schizophrenia. The American Journal of Psychiatry 174(3): 286-295. DOI: 10.1176/appi.ajp.2016.16050610.

Ducharme S, Dols A, Laforce R, et al. (2020) Recommendations to distinguish behavioural variant frontotemporal dementia from psychiatric disorders. Brain 143(6). Oxford University Press (OUP): 1632-1650. DOI: 10.1093/brain/awaa018.

Eratne D, Loi SM, Walia N, et al. (2020) A pilot study of the utility of cerebrospinal fluid neurofilament light chain in differentiating neurodegenerative from psychiatric disorders: A 'C-reactive protein' for psychiatrists and neurologists? Australian and New Zealand Journal of Psychiatry 54(1): 57-67. DOI: 10.1177/0004867419857811.

Eratne D, Loi SM, Li QX, et al. (2020) Cerebrospinal fluid neurofilament light chain is elevated in Niemann-Pick type C compared to psychiatric disorders and healthy controls and may be a marker of treatment response. Australian and New Zealand Journal of Psychiatry 54(6): 648-649. DOI: 10.1177/0004867419893431.

Forsyth JK and Lewis DA (2017) Mapping the Consequences of Impaired Synaptic Plasticity in Schizophrenia through Development: An Integrative Model for Diverse Clinical Features. Trends in Cognitive Sciences 21(10): 760-778. DOI: 10.1016/j.tics.2017.06.006.

Gaetani L, Blennow K, Calabresi P, et al. (2019) Neurofilament light chain as a biomarker in neurological disorders. Journal of Neurology, Neurosurgery \& Psychiatry 90(8): 870881. DOI: 10.1136/jnnp-2018-320106.

Gudmundsson P, Skoog I, Waern M, et al. (2010) Is there a CSF biomarker profile related to depression in elderly women? Psychiatry Research 176(2-3). Elsevier Ltd: 174-178. DOI: 10.1016/j.psychres.2008.11.012.

Howes OD, McCutcheon R, Agid O, et al. (2017) Treatment-Resistant Schizophrenia: Treatment Response and Resistance in Psychosis (TRRIP) Working Group Consensus Guidelines on Diagnosis and Terminology. American Journal of Psychiatry 174(3): 216-229. DOI: 10.1176/appi.ajp.2016.16050503.

Jakobsson J, Bjerke M, Ekman CJ, et al. (2014) Elevated concentrations of neurofilament light chain in the cerebrospinal fluid of bipolar disorder patients. Neuropsychopharmacology 39(10): 2349-2356. DOI: 10.1038/npp.2014.81.

Kahn RS, Sommer IE, Murray RM, et al. (2015) Schizophrenia. Nature Reviews Disease Primers 1(1): 15067. DOI: 10.1038/nrdp.2015.67. 
Kass RE and Raftery AE (1995) Bayes Factors. Journal of the American Statistical Association 90(430): 773-795. DOI: 10.1080/01621459.1995.10476572.

Katisko K, Cajanus A, Jääskeläinen O, et al. (2020) Serum neurofilament light chain is a discriminative biomarker between frontotemporal lobar degeneration and primary psychiatric disorders. Journal of Neurology 267(1): 162-167. DOI: 10.1007/s00415019-09567-8.

Kelly S, Jahanshad N, Zalesky A, et al. (2018) Widespread white matter microstructural differences in schizophrenia across 4322 individuals: results from the ENIGMA Schizophrenia DTI Working Group. Molecular Psychiatry 23(5): 1261-1269. DOI: 10.1038/mp.2017.170.

Khalil M, Teunissen CE, Otto M, et al. (2018) Neurofilaments as biomarkers in neurological disorders. Nature Reviews Neurology 14(10). Nature Publishing Group: 577-589. DOI: 10.1038/s41582-018-0058-z.

Kochunov P and Hong LE (2014) Neurodevelopmental and Neurodegenerative Models of Schizophrenia: White Matter at the Center Stage. Schizophrenia Bulletin 40(4): 721728. DOI: 10.1093/schbul/sbu070.

Kuhle J, Kropshofer H, Haering DA, et al. (2019) Blood neurofilament light chain as a biomarker of MS disease activity and treatment response. Neurology 92(10): e1007e1015. DOI: 10.1212/WNL.0000000000007032.

Manouchehrinia A, Piehl F, Hillert J, et al. (2020) Confounding effect of blood volume and body mass index on blood neurofilament light chain levels. Annals of Clinical and Translational Neurology 7(1): 139-143. DOI: 10.1002/acn3.50972.

McCutcheon RA, Reis Marques T and Howes OD (2020) Schizophrenia-An Overview. JAMA Psychiatry 77(2): 201. DOI: 10.1001/jamapsychiatry.2019.3360.

Mostaid MS, Lee TT, Chana G, et al. (2017) Elevated peripheral expression of neuregulin-1 (NRG1) mRNA isoforms in clozapine-treated schizophrenia patients. Translational Psychiatry 7(12): 1280. DOI: 10.1038/s41398-017-0041-2.

Nilsson IAK, Millischer V, Karrenbauer VD, et al. (2019) Plasma neurofilament light chain concentration is increased in anorexia nervosa. Translational Psychiatry. DOI: 10.1038/s41398-019-0518-2.

Pantelis C, Velakoulis D, McGorry PD, et al. (2003) Neuroanatomical abnormalities before and after onset of psychosis: a cross-sectional and longitudinal MRI comparison. Lancet (London, England) 361(9354): 281-288. DOI: 10.1016/S0140-6736(03)123239.

Pantelis C, Yücel M, Wood SJ, et al. (2005) Structural brain imaging evidence for multiple pathological processes at different stages of brain development in schizophrenia. Schizophrenia Bulletin 31(3): 672-696. DOI: 10.1093/schbul/sbi034. 
Pantelis C, Wood SJ, Proffitt TM, et al. (2009) Attentional set-shifting ability in first-episode and established schizophrenia: Relationship to working memory. Schizophrenia Research 112(1-3): 104-113. DOI: 10.1016/j.schres.2009.03.039.

Pantelis C, Yücel M, Bora E, et al. (2009) Neurobiological Markers of Illness Onset in Psychosis and Schizophrenia: The Search for a Moving Target. Neuropsychology Review 19(3): 385-398. DOI: 10.1007/s11065-009-9114-1.

Potkin SG, Kane JM, Correll CU, et al. (2020) The neurobiology of treatment-resistant schizophrenia: paths to antipsychotic resistance and a roadmap for future research. npj Schizophrenia 6(1): 1. DOI: 10.1038/s41537-019-0090-z.

Rodrigues-Amorim D, Rivera-Baltanás T, del Carmen Vallejo-Curto M, et al. (2020) Plasma $\beta$ III tubulin, neurofilament light chain and glial fibrillary acidic protein are associated with neurodegeneration and progression in schizophrenia. Scientific Reports 10(1): 14271. DOI: 10.1038/s41598-020-71060-4.

Rouder JN, Speckman PL, Sun D, et al. (2009) Bayesian t tests for accepting and rejecting the null hypothesis. Psychonomic Bulletin \& Review 16(2): 225-237. DOI: 10.3758/PBR.16.2.225.

Rund B (2009) Is there a degenerative process going on in the brain of people with schizophrenia? Frontiers in Human Neuroscience 3. DOI: 10.3389/neuro.09.036.2009.

Ryan JJ and Lopez SJ (2001) Wechsler Adult Intelligence Scale-III. In: Dorfman WI and Hersen M (eds) Understanding Psychological Assessment. Boston, MA: Springer US, pp. 1942. DOI: 10.1007/978-1-4615-1185-4_2.

Spotorno N, Lindberg O, Nilsson C, et al. (2020) Plasma neurofilament light protein correlates with diffusion tensor imaging metrics in frontotemporal dementia. PLOS ONE Najbauer J (ed.) 15(10): e0236384. DOI: 10.1371/journal.pone.0236384.

van Erp TGM, Walton E, Hibar DP, et al. (2018) Cortical Brain Abnormalities in 4474 Individuals With Schizophrenia and 5098 Control Subjects via the Enhancing Neuro Imaging Genetics Through Meta Analysis (ENIGMA) Consortium. Biological Psychiatry 84(9): 644-654. DOI: 10.1016/j.biopsych.2018.04.023.

Velakoulis D, Wood SJ, Wong MTH, et al. (2006) Hippocampal and amygdala volumes according to psychosis stage and diagnosis: a magnetic resonance imaging study of chronic schizophrenia, first-episode psychosis, and ultra-high-risk individuals. Archives of General Psychiatry 63(2): 139-149. DOI: 10.1001/archpsyc.63.2.139.

Velakoulis D, Walterfang M, Mocellin R, et al. (2009) Frontotemporal dementia presenting as schizophrenia-like psychosis in young people: Clinicopathological series and review of cases. British Journal of Psychiatry 194(4): 298-305. DOI:

10.1192/bjp.bp.108.057034. 
Vita A, Minelli A, Barlati S, et al. (2019) Treatment-Resistant Schizophrenia: Genetic and Neuroimaging Correlates. Frontiers in Pharmacology 10: 402. DOI: 10.3389/fphar.2019.00402.

Wannan CMJ, Bartholomeusz CF, Cropley VL, et al. (2018) Deterioration of visuospatial associative memory following a first psychotic episode: a long-term follow-up study. Psychological Medicine 48(1): 132-141. DOI: 10.1017/S003329171700157X.

Yuan A, Rao MV, Veeranna, et al. (2017) Neurofilaments and neurofilament proteins in health and disease. Cold Spring Harbor Perspectives in Biology 9(4). Cold Spring Harbor Laboratory Press: 1-24. DOI: 10.1101/cshperspect.a018309.

Zachrisson OCG, Balldin J, Ekman R, et al. (2000) No evident neuronal damage after electroconvulsive therapy. Psychiatry Research 96(2): 157-165. DOI: 10.1016/S01651781(00)00202-X.

Zerr I, Schmitz M, Karch A, et al. (2018) Cerebrospinal fluid neurofilament light levels in neurodegenerative dementia: evaluation of diagnostic accuracy in the differential diagnosis of prion diseases. Alzheimer's \& Dementia 14(6). Elsevier: 751-763. 
TABLES AND FIGURES

Table 1

\begin{tabular}{|c|c|c|c|c|c|}
\hline & Schizophrenia & & & $\begin{array}{l}\text { Family } \\
\text { member }\end{array}$ & \\
\hline & $\begin{array}{l}\text { Treatment } \\
\text { resistant }\end{array}$ & $\begin{array}{l}\text { Non-clozapine } \\
\text { treated }\end{array}$ & Control & Sibling & Parent \\
\hline $\mathbf{N}$ & 82 & 13 & 59 & 21 & 16 \\
\hline Age at sample, $y$ & $\begin{array}{l}40.3[38.4, \\
42.4]\end{array}$ & $37.9[32.0,43.6]$ & $\begin{array}{l}39.6 \\
{[36.9,} \\
42.1] \\
\end{array}$ & $\begin{array}{l}43.0 \\
{[37.1,} \\
48.6]\end{array}$ & \begin{tabular}{|l|}
65.9 \\
{$[62.0$} \\
$69.8]$ \\
\end{tabular} \\
\hline Sex, n female (\%) & $23(28 \%)$ & $8(62 \%)$ & $\begin{array}{l}22 \\
(37 \%)\end{array}$ & $15(71 \%)$ & \begin{tabular}{|l|}
13 \\
$(13 \%)$
\end{tabular} \\
\hline Age at onset & $\begin{array}{l}22.6[21.2 \\
24.0](n=78)\end{array}$ & $19.9[17.3,22.5]]$ & - & - & - \\
\hline Duration of illness, $y$ & \begin{tabular}{|l|}
$17.6[15.6$ \\
$19.6](n=78)$
\end{tabular} & $17.9[11.7,24.2]$ & - & - & - \\
\hline PANSS positive & $\begin{array}{l}15.9[14.6, \\
17.5] \\
(n=77)\end{array}$ & $\begin{array}{l}14.3[11.2,17.2] \\
(n=12)\end{array}$ & $\begin{array}{l}7.2 \\
{[7.1} \\
7.4]\end{array}$ & $\begin{array}{l}7.4[7.1 \\
7.8]\end{array}$ & $\begin{array}{l}7.1[7.0, \\
7.3]\end{array}$ \\
\hline PANSS negative & $\begin{array}{l}20.9[18.6 \\
23.3](n=25)\end{array}$ & $\begin{array}{l}13.8[8.3,20.2] \\
(n=5)\end{array}$ & - & - & - \\
\hline PANSS general & $\begin{array}{l}32.3[29.6, \\
35.5](n=26)\end{array}$ & $\begin{array}{l}24.4[19.5,29.0] \\
(n=5)\end{array}$ & - & - & - \\
\hline PANSS total & $\begin{array}{l}69.9[64.7 \\
74.8](n=24)\end{array}$ & $\begin{array}{l}50.4[39.4,61.2] \\
(n=5)\end{array}$ & - & - & - \\
\hline Years of schooling & $\begin{array}{l}12.2[11.6 \\
12.9]\end{array}$ & $13.5[11.6,15.4]$ & $\begin{array}{l}16.3 \\
{[15.6,} \\
17.1] \\
\end{array}$ & $\begin{array}{l}16.9 \\
{[15.8,} \\
18]\end{array}$ & \begin{tabular}{|l|}
13.5 \\
{$[11.2$,} \\
$15.8]$ \\
\end{tabular} \\
\hline $\begin{array}{l}\text { Current smoker (last } 12 \\
\text { months) }\end{array}$ & $42 / 75(56 \%)$ & $5(38 \%)$ & $\begin{array}{l}11 \\
(18 \%)\end{array}$ & $1(5 \%)$ & \begin{tabular}{|l|}
$4 / 15$ \\
$(27 \%)$
\end{tabular} \\
\hline $\begin{array}{l}\text { Alcohol use disorder } \\
\text { diagnosis }\end{array}$ & $21(25 \%)$ & $1(10 \%)$ & $\begin{array}{l}10 \\
(17 \%)\end{array}$ & $2(10 \%)$ & $1(6 \%)$ \\
\hline Hypertension & $12 / 78(15 \%)$ & $2 / 9(22 \%)$ & $2(3 \%)$ & $3(14 \%)$ & $7(44 \%)$ \\
\hline Diabetes & $6 / 78(8 \%)$ & $1 / 9(11 \%)$ & $0 \%$ & $0 \%$ & $1(13 \%)$ \\
\hline Dyslipidaemia & $16(21 \%)$ & $1(8 \%)$ & $0 \%$ & $1(5 \%)$ & $4(25 \%)$ \\
\hline BMI & $\begin{array}{l}31.4[29.8 \\
33.1](n=67)\end{array}$ & $\begin{array}{l}31.0[26.8,35.5] \\
(n=12)\end{array}$ & $\begin{array}{l}24.9 \\
{[23.1} \\
26.6] \\
(n=54) \\
\end{array}$ & $\begin{array}{l}28.9 \\
{[26.2,} \\
32] \\
(n=20) \\
\end{array}$ & $\begin{array}{l}31.6 \\
{[27.0} \\
36.1] \\
(n=12) \\
\end{array}$ \\
\hline Weight, kg & $\begin{array}{l}95.8[90.2 \\
101.5](n=71)\end{array}$ & $\begin{array}{l}89.7[77.7,101.2] \\
(n=12)\end{array}$ & $\begin{array}{l}75.0 \\
{[72.2,} \\
78.1] \\
(n=54) \\
\end{array}$ & $\begin{array}{l}81.3 \\
{[74.4,} \\
89.0] \\
(n=20) \\
\end{array}$ & \begin{tabular}{|l|}
81.1 \\
{$[67.6$} \\
$94.2]$ \\
$(n=13)$ \\
\end{tabular} \\
\hline WASI_IQ & \begin{tabular}{|l|}
$86.0[82.2$ \\
$89.8](n=76)$
\end{tabular} & $\begin{array}{l}106.6[99.1 \\
113.5](n=12)\end{array}$ & $\begin{array}{l}111.6 \\
{[107.7,} \\
115.0]\end{array}$ & $\begin{array}{l}116.5 \\
{[112.7,} \\
120.4]\end{array}$ & \begin{tabular}{|l|}
113.2 \\
{$[102.2$} \\
$124.0]$ \\
\end{tabular} \\
\hline Clozapine level, ug/L & $\begin{array}{l}433.4[383.4 \\
488.4](n=80)\end{array}$ & - & - & - & - \\
\hline Functioning SOFAS & $\begin{array}{l}46.9[43.8, \\
50.1]\end{array}$ & $56.2[48.4,64.4]$ & $\begin{array}{l}79.3 \\
{[76.6} \\
82.3]\end{array}$ & $\begin{array}{l}79.4 \\
{[47.8,} \\
83.6]\end{array}$ & \begin{tabular}{|l|}
79 \\
{$[74.9$} \\
$82.2]$ \\
\end{tabular} \\
\hline Any history of head injury & $32 / 81(40 \%)$ & $5(38 \%)$ & $\begin{array}{l}10 \\
(17 \%) \\
\end{array}$ & $3(14 \%)$ & $2(13 \%)$ \\
\hline Epilepsy & $12 / 80(15 \%)$ & $0 / 9(0 \%)$ & $1(2 \%)$ & $0 \%$ & $0 \%$ \\
\hline $\begin{array}{l}\text { Other neurological } \\
\text { disorder diagnosis }\end{array}$ & $5(6 \%)$ & $0 \%$ & $0 \%$ & $0 \%$ & $1(6 \%)$ \\
\hline Ever had ECT & $25 / 78(32 \%)$ & $0 \%$ & $0 \%$ & $0 \%$ & $0 \%$ \\
\hline
\end{tabular}

Page 32 of 45 
Table 1. Demographics

Data is Mean, [95\% Cl, bootstrapped 1000 replicates and bias corrected] or $n,(\%)$

BMI: body mass index; ECT: electroconvulsive therapy; PANSS: Positive and Negative Syndrome Scale; SOFAS: Social and Occupational Functioning Assessment Scale 


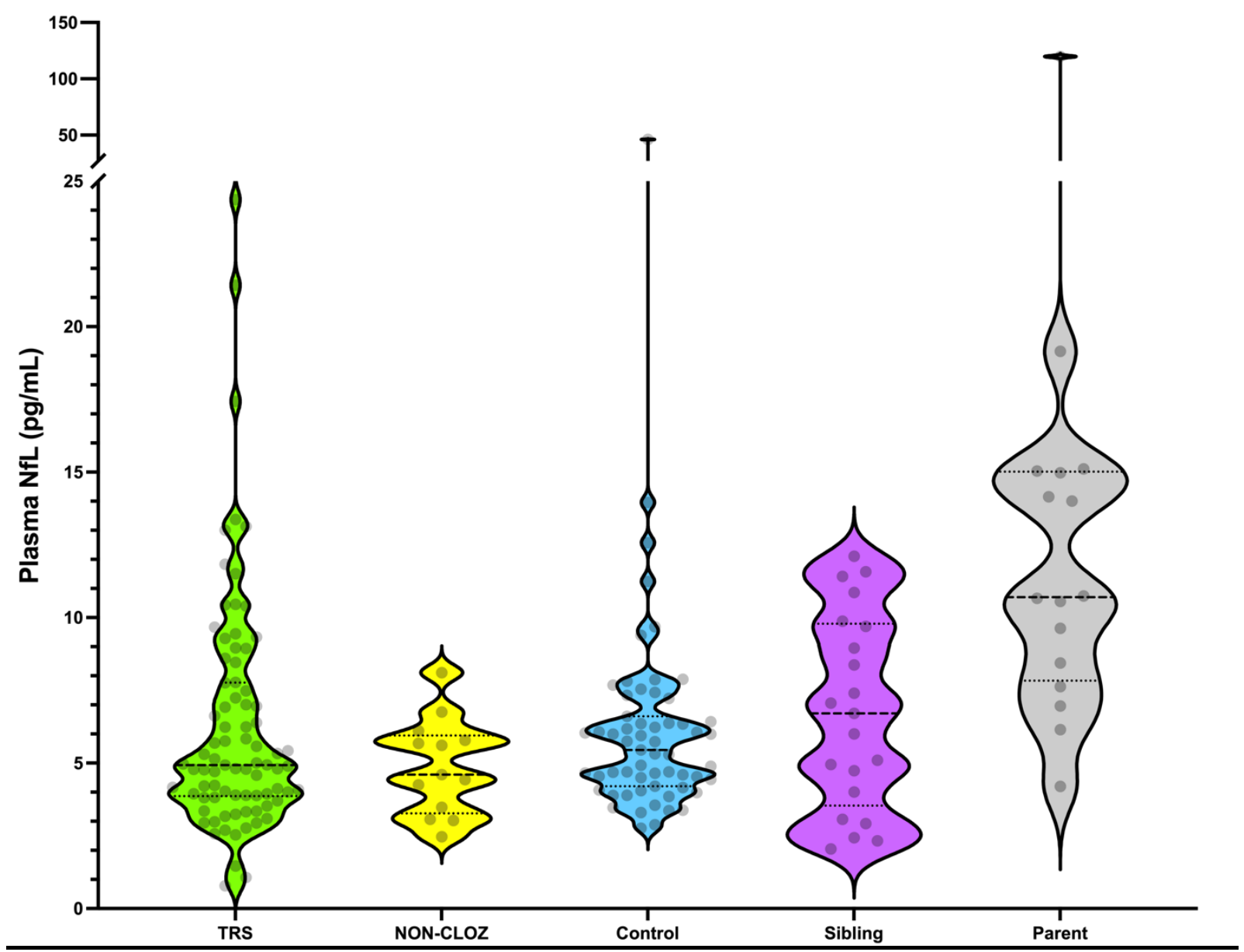

Figure 1. Plasma neurofilament light chain levels in treatment-resistant schizophrenia, non-clozapine treated schizophrenia, controls, and unaffected siblings and parents. Violin plot with scatter. Width of distribution of points proportionate to number of points at that $Y$ value. Dashed line=median. Dotted lines=quartiles. NfL: neurofilament light protein; NON-CLOZ: schizophrenia not on clozapine; TRS: treatment-resistant schizophrenia on clozapine. 


\begin{tabular}{|c|c|c|c|c|c|}
\hline & Schizophrenia & & & $\begin{array}{l}\text { Family } \\
\text { member }\end{array}$ & \\
\hline & $\begin{array}{l}\text { Treatment } \\
\text { resistant }\end{array}$ & $\begin{array}{l}\text { Non- } \\
\text { clozapine } \\
\text { treated }\end{array}$ & Control & Sibling & Parent \\
\hline $\mathbf{N}$ & 82 & 13 & $58^{a}$ & 21 & $15^{\mathrm{b}}$ \\
\hline Age at sample, y & $\begin{array}{l}40.3[38.4, \\
42.4]\end{array}$ & $\begin{array}{l}37.9 \\
{[32.0} \\
43.6]\end{array}$ & $\begin{array}{l}39.5 \\
{[37.0} \\
42.1]\end{array}$ & $\begin{array}{l}43.0 \\
{[37.1} \\
42.5]\end{array}$ & $\begin{array}{l}65.8^{\mathrm{C}}[61.3, \\
70.2]\end{array}$ \\
\hline Female & $23(28 \%)$ & $8(62 \%)$ & $\begin{array}{l}22 \\
(38 \%)\end{array}$ & $\begin{array}{l}15 \\
(71 \%)\end{array}$ & $12(80 \%)$ \\
\hline $\begin{array}{l}\text { Neurofilament light } \\
\text { chain, } \mathrm{pg} / \mathrm{mL}\end{array}$ & $6.3[5.5,7.2]$ & $\begin{array}{l}4.9[4.0 \\
5.8]\end{array}$ & $\begin{array}{l}5.8 \\
{[5.3} \\
6.3]^{d}\end{array}$ & $\begin{array}{l}6.7[5.2, \\
8.2]\end{array}$ & $\begin{array}{l}11.2[9.2 \\
13.4]^{e, f}\end{array}$ \\
\hline
\end{tabular}

Table 2. Neurofilament light in treatment-resistant and non-clozapine treated schizophrenia, siblings, parents and control groups

Data is Mean, [ $95 \% \mathrm{Cl}$, bootstrapped 1000 replicates and bias corrected] or $\mathrm{n},(\%)$

a: excluding an extreme outlier (NfL 46.2pg/mL)

b: excluding an extreme outlier (NfL 119.8pg/mL)

c: greater than all other groups

$\mathrm{d}$ : including the extreme outlier (NfL $46.2 \mathrm{pg} / \mathrm{mL}$ ) resulted in mean and $95 \%$ confidence intervals for $n=59$ controls: $6.5 \mathrm{pg} / \mathrm{mL}[5.4,7.9]$

e: Including the extreme outlier (NfL 119.8pg/mL) resulted in mean and $95 \%$ confidence intervals for $n=16$ parents: $18.0 \mathrm{pg} / \mathrm{mL}[9.8,33.7]$

f: after adjusting for age in this older group, levels were not statistically elevated compared to other groups (estimated marginal mean: $6.7 \mathrm{pg} / \mathrm{mL}[4.7,8.8]$; including extreme outlier: $13.3 \mathrm{pg} / \mathrm{mL}[5.3,25.8])$ 
SUPPLEMENTARY MATERIAL

\begin{tabular}{|c|c|c|c|c|c|c|}
\hline $\begin{array}{l}\text { Control } \\
\text { percentile }^{a, b}\end{array}$ & $\begin{array}{l}\text { TRS } \\
(n=82)\end{array}$ & $\begin{array}{l}\text { P- } \\
\text { value } \\
\text { (TRS } \\
\text { vs C) }\end{array}$ & $\begin{array}{l}\text { NON- } \\
\text { CLOZ } \\
(n=13)\end{array}$ & $\begin{array}{l}\text { P-value } \\
\text { (NON-CLOZ } \\
\text { vs C) }{ }^{c}\end{array}$ & $\begin{array}{l}\text { Siblings } \\
(n=21)\end{array}$ & $\begin{array}{l}\text { P-value } \\
\text { (siblings vs } \\
\text { C) }\end{array}$ \\
\hline $\begin{array}{l}80^{\text {th }} \\
\text { percentile, } \\
\text { n (\%) }\end{array}$ & $22(27 \%)$ & 0.223 & $1(8 \%)$ & 0.676 & $8(38 \%)$ & 0.07 \\
\hline $\begin{array}{l}90^{\text {th }} \\
\text { percentile, } \\
\text { n (\%) }\end{array}$ & $19(23 \%)$ & $\underline{0.039}$ & $1(8 \%)$ & 1.000 & $8(38 \%)$ & $\leq 0.001$ \\
\hline $\begin{array}{l}95^{\text {th }} \\
\text { percentile, } \\
\text { n (\%) }\end{array}$ & $8(10 \%)$ & 0.195 & 0 & 1.000 & $3(14 \%)$ & 0.114 \\
\hline $\begin{array}{l}98^{\text {th }} \\
\text { percentile, } \\
\text { n (\%) }\end{array}$ & $3(4 \%)$ & 0.642 & 0 & 1.000 & 0 & 1.000 \\
\hline
\end{tabular}

Supplementary Table 1. Additional analyses to explore percentile distributions in different groups.

Underlined and bold values show $p<0.05$.

a: $80^{\text {th }}$ percentile: $7.3 \mathrm{pg} / \mathrm{mL}, 90^{\text {th }}$ percentile: $8.0 \mathrm{pg} / \mathrm{mL}, 95^{\text {th }}$ percentile: $11.3 \mathrm{pg} / \mathrm{mL}$, $98^{\text {th }}$ percentile: $13.7 \mathrm{pg} / \mathrm{mL}, 99^{\text {th }}$ percentile: N/A

$\mathrm{b}$ : excluding extreme outlier in control group

c: Fisher's Exact Test used to compare numbers in each percentile allocation in TRS, NON-CLOZ and siblings, compared to controls.

C: control; NON-CLOZ: non-clozapine treated schizophrenia; TRS: treatmentresistant schizophrenia 


\begin{tabular}{|l|l|l|l|l|}
\hline Comparison & Levene's test & $\begin{array}{l}\text { Student's t- } \\
\text { test }\end{array}$ & Welch's t-test & $\begin{array}{l}\text { Robust group } \\
\text { term }\end{array}$ \\
\hline $\begin{array}{l}\text { TRS vs } \\
\text { control }\end{array}$ & $\underline{\mathbf{0 . 0 0 3}}$ & 0.43 & 0.38 & $\begin{array}{l}0.34[- \\
0.61,1.29]\end{array}$ \\
\hline $\begin{array}{l}\text { NON-CLOZ } \\
\text { vs control }\end{array}$ & 0.53 & 0.17 & 0.10 & $\begin{array}{l}0.79[-0.16, \\
1.74]\end{array}$ \\
\hline $\begin{array}{l}\text { Sibling vs } \\
\text { control }\end{array}$ & $\underline{\mathbf{0 . 0 0 3}}$ & 0.15 & 0.24 & $\begin{array}{l}0.56[-0.73, \\
1.85]\end{array}$ \\
\hline $\begin{array}{l}\text { Parent vs } \\
\text { control }\end{array}$ & $\underline{\mathbf{0 0 . 0 0 1}}$ & $\mathbf{\leq 0 . 0 0 1}$ & $\underline{<0.001}$ & $\begin{array}{l}2.33[-0.21, \\
4.87]\end{array}$ \\
\hline $\begin{array}{l}\text { NON-CLOZ } \\
\text { vs TRS }\end{array}$ & 0.06 & 0.23 & 0.04 & $\begin{array}{l}0.83[-0.48, \\
2.15]\end{array}$ \\
\hline
\end{tabular}

Supplementary Table 2. Additional sensitivity analyses to determine impact of heterogeneity of variances on group differences.

Underlined and bold values show $p<0.05$. As described in the text, taken together, these sensitivity analyses suggest that heterogeneity of variances does not explain the lack of statistically significant group differences.

NON-CLOZ: non-clozapine treated schizophrenia; TRS: treatment-resistant schizophrenia 


\begin{tabular}{|c|c|c|c|}
\hline \multirow[t]{2}{*}{$\begin{array}{l}\text { Confidence Intervals of Spearman's } \\
\text { rho in TRS group }\end{array}$} & \multirow[b]{2}{*}{ Spearman's rho } & & \\
\hline & & \multicolumn{2}{|c|}{ 95\% Confidence Intervals (2-tailed)a,b } \\
\hline & & Lower & Upper \\
\hline NfLValue - AgeAtSample & $0.674 *$ & 0.531 & 0.78 \\
\hline NfLValue - SexFEMALE & 0.178 & -0.047 & 0.386 \\
\hline NfLValue - Duration of IIIness & $0.467 *$ & 0.267 & 0.629 \\
\hline NfLValue - PANSSPositiveScale & -0.016 & -0.24 & 0.209 \\
\hline NfLValue - PANSSNegativeScale & -0.06 & -0.281 & 0.166 \\
\hline NfLValue - PANSSGeneral & 0.108 & -0.12 & 0.325 \\
\hline NfLValue - school_years & -0.029 & -0.251 & 0.197 \\
\hline NfLValue - CurrentSmokerYesNo & -0.175 & -0.392 & 0.061 \\
\hline NfLValue - Alcohol use disorder & -0.199 & -0.404 & 0.025 \\
\hline NfLValue - HTN & 0.202 & -0.027 & 0.411 \\
\hline NfLValue - Diabetes & 0.115 & -0.117 & 0.335 \\
\hline NfLValue - Dyslipidaemia & $0.273 *$ & 0.053 & 0.468 \\
\hline NfLValue - BMI_calculated & $-0.264 *$ & -0.48 & -0.019 \\
\hline NfLValue - weight & $-0.316 *$ & -0.516 & -0.082 \\
\hline NfLValue - wasi_iq & 0.139 & -0.096 & 0.36 \\
\hline NfLValue - ClozapineLevel & $0.258 *$ & 0.034 & 0.457 \\
\hline NfLValue - SOFAS & -0.039 & -0.266 & 0.191 \\
\hline NfLValue - head_injury & -0.084 & -0.303 & 0.143 \\
\hline NfLValue - epil & 0.036 & -0.191 & 0.26 \\
\hline $\begin{array}{l}\text { NfLValue - } \\
\text { NeurologicalDisorderDiagnosis }\end{array}$ & -0.037 & -0.259 & 0.187 \\
\hline NfLValue - ect & -0.076 & -0.3 & 0.155 \\
\hline
\end{tabular}

Supplementary Table 3. Exploratory analyses of associations between NfL and clinical variables in the treatment-resistant schizophrenia group *: Statistically significant (Spearman's rho 95\% confidence intervals don't include zero)

BMI: body mass index; ECT: electroconvulsive therapy; GAF: Global Assessment of Functioning scale; NfL: neurofilament light; PANSS: Positive and Negative Syndrome Scale; SOFAS: Social and Occupational Functioning Assessment Scale

a: Estimation is based on Fisher's r-to-z transformation.

b: Estimation of standard error is based on the formula proposed by Fieller, Hartley, and Pearson. 


\section{Figures}

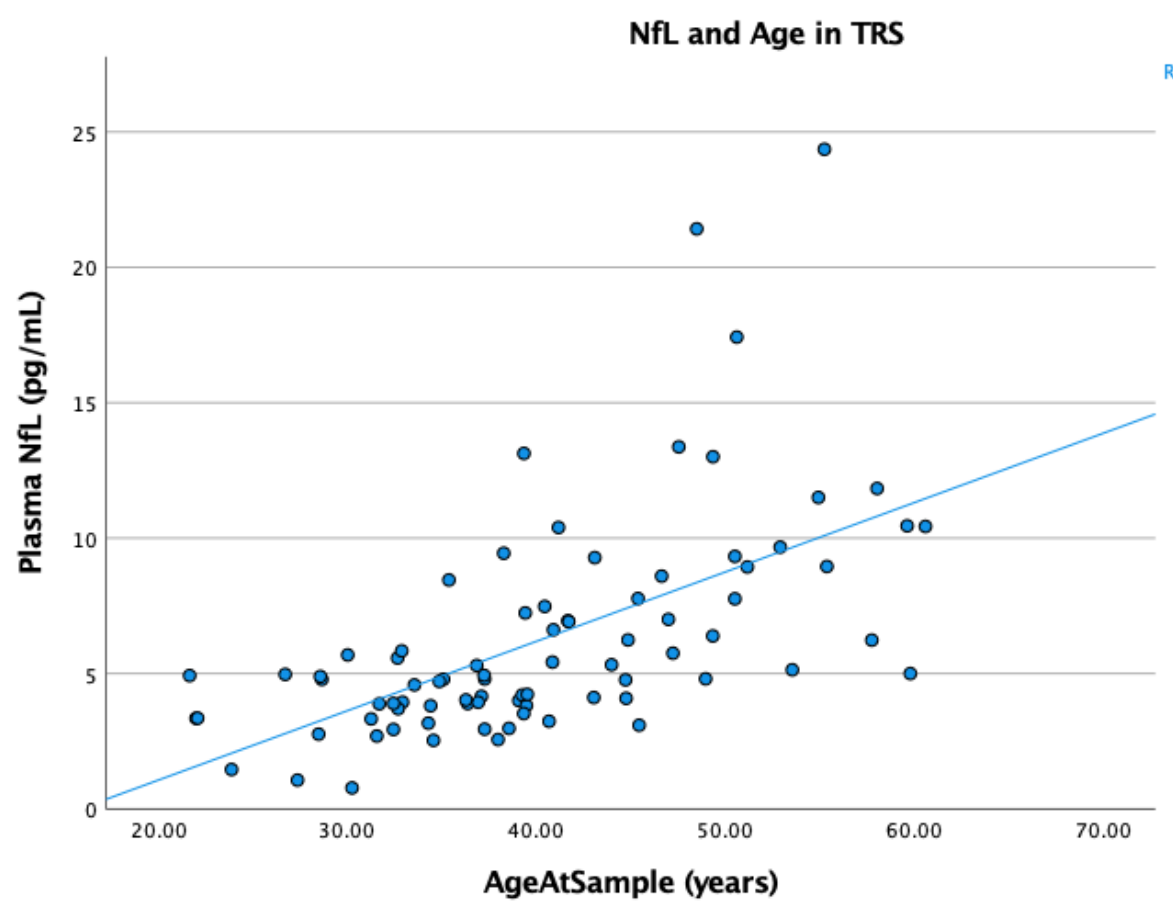

Supplementary Figure 1. Plasma neurofilament light versus age at blood sample in the treatment-resistant schizophrenia group

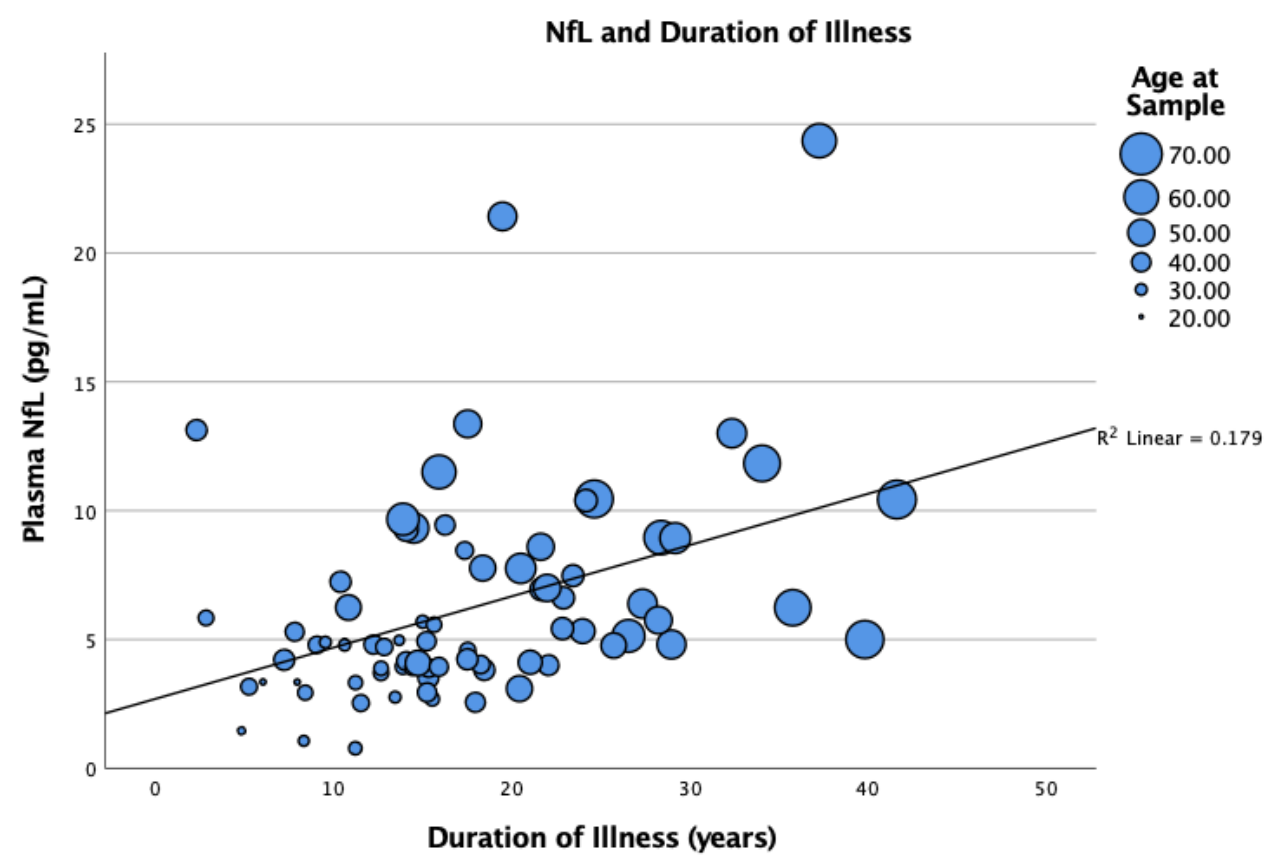

Supplementary Figure 2. Plasma neurofilament light versus duration of illness in the treatment-resistant schizophrenia group 


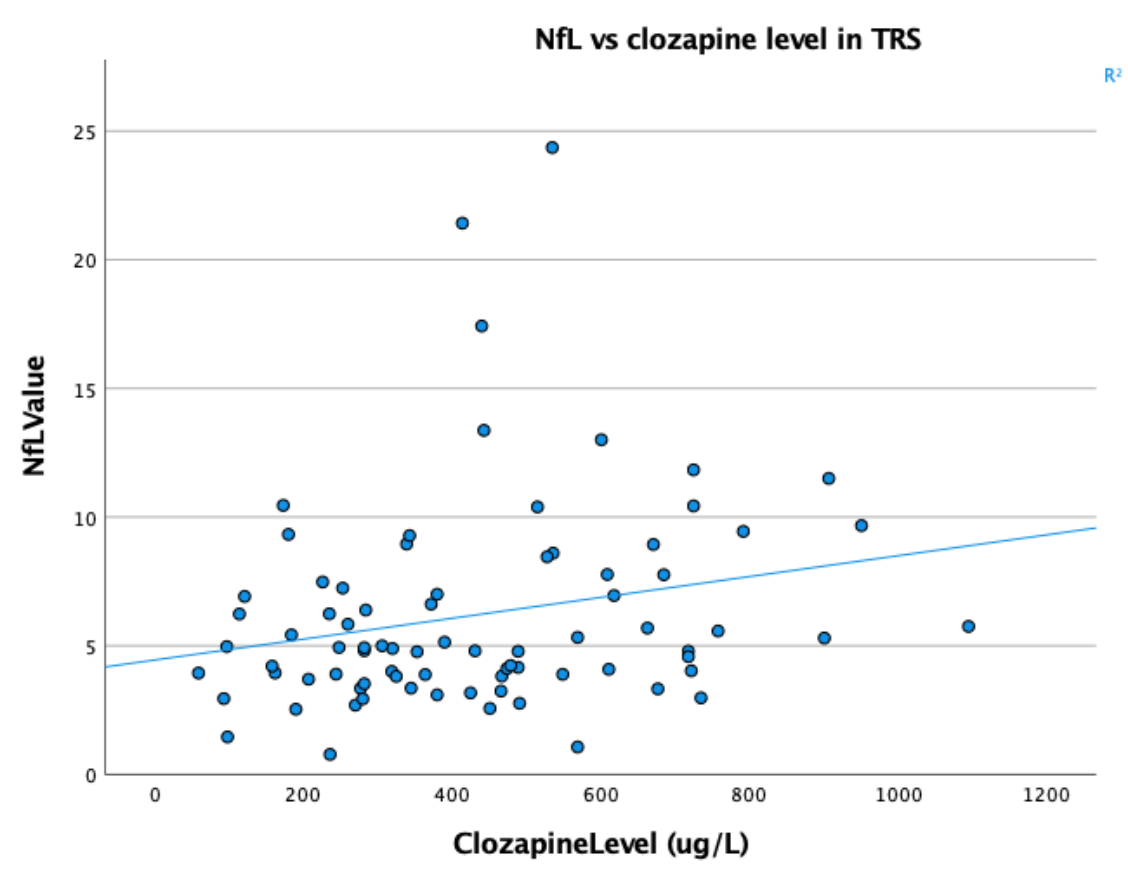

Supplementary Figure 3. Plasma neurofilament light versus clozapine level in the treatment-resistant schizophrenia group

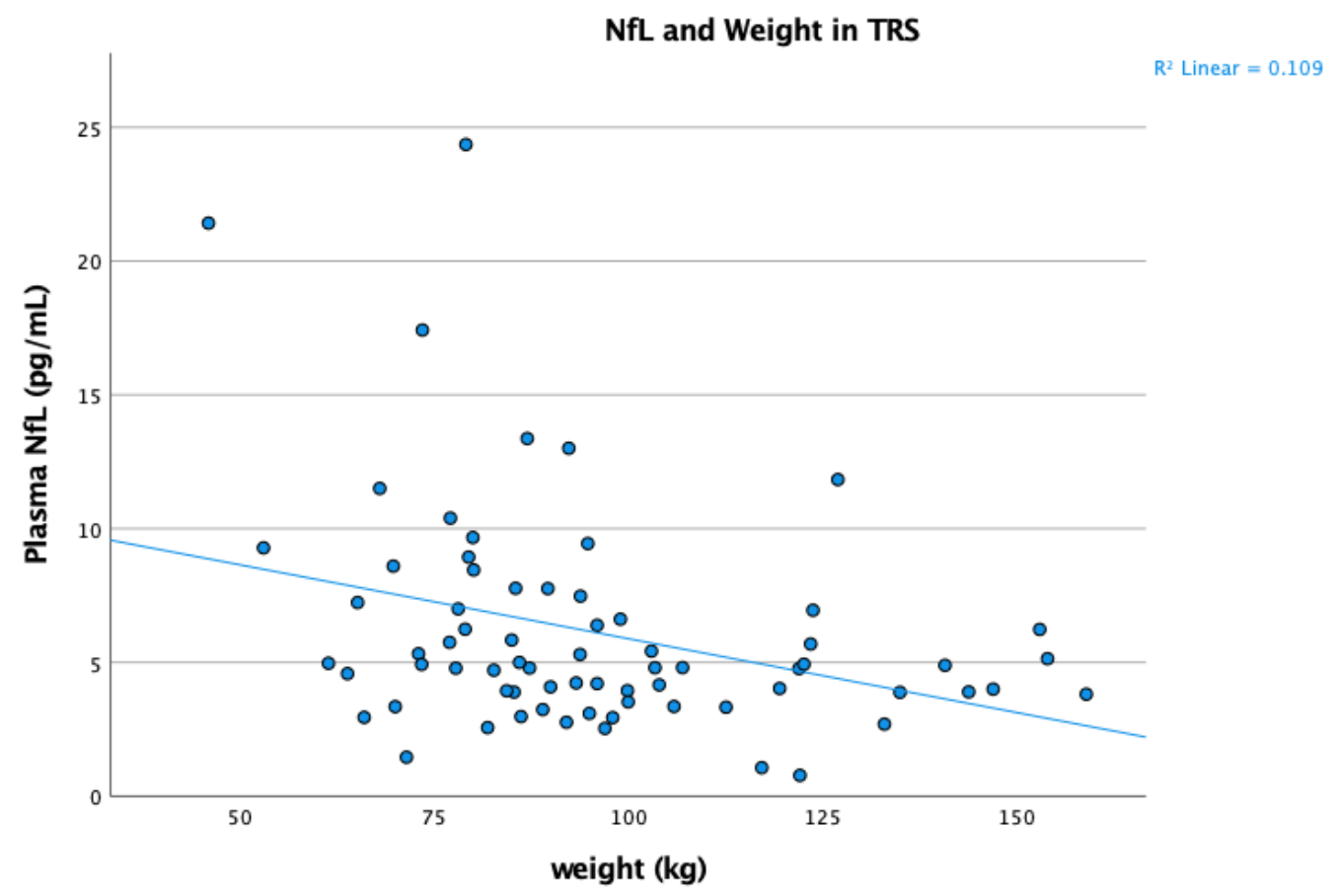

Supplementary Figure 4. Plasma neurofilament light versus weight in the treatment-resistant schizophrenia group 


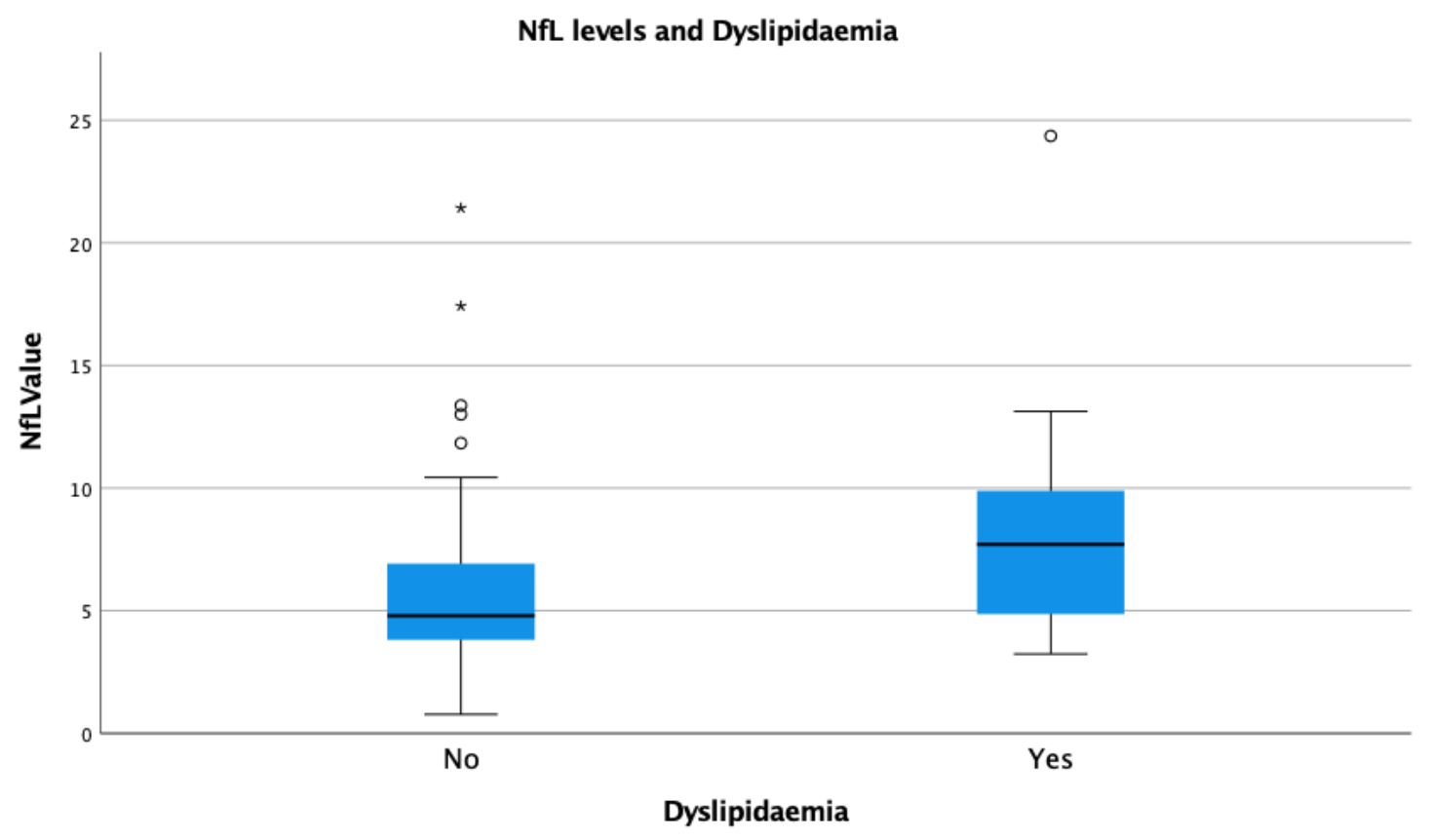

Supplementary Figure 5. Plasma neurofilament light levels in people with and without dyslipidaemia in the treatment-resistant schizophrenia group 


\section{APPENDIX 1}

COLLABORATORS:

On behalf of others in The MiND Study Group:

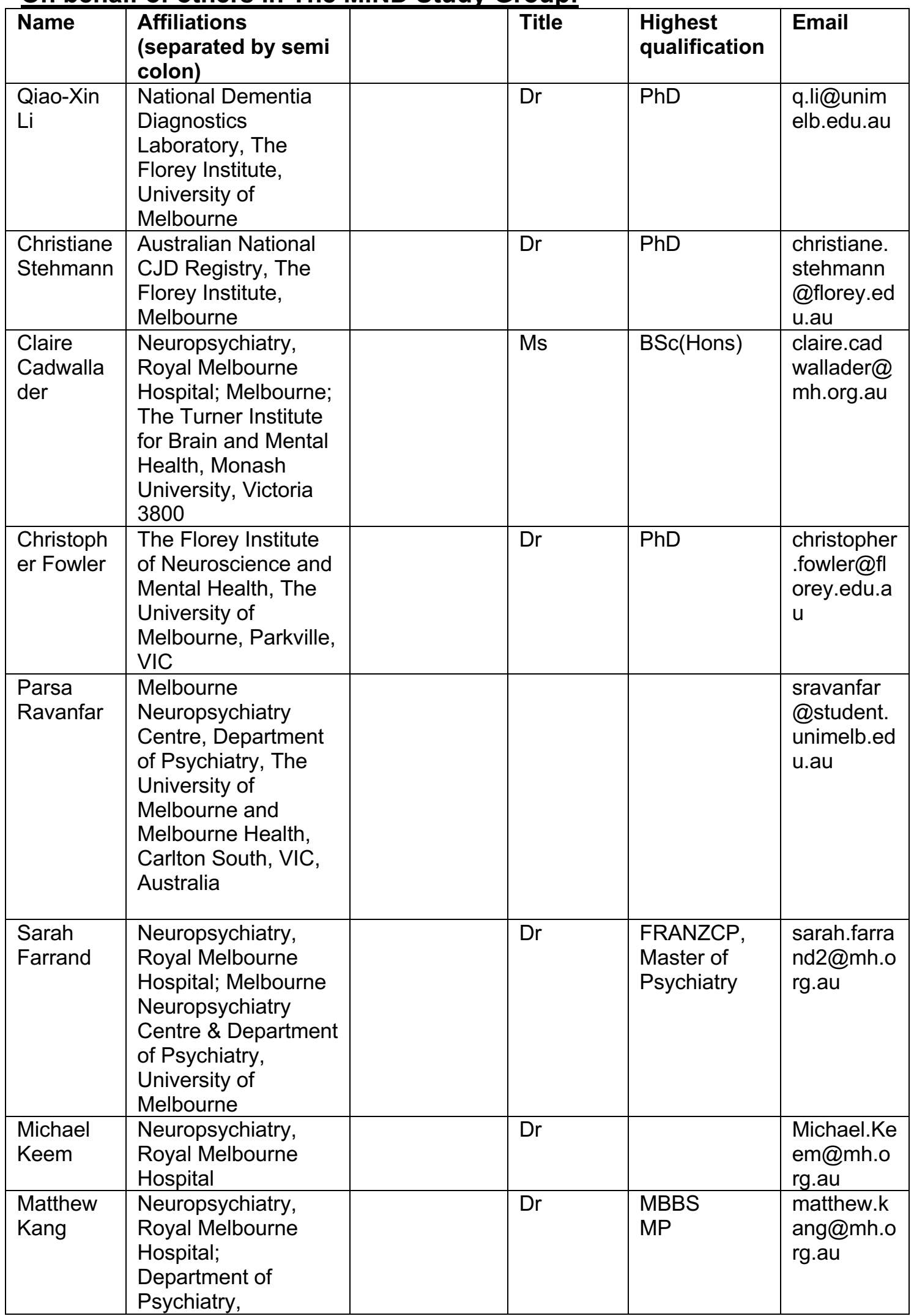

Page 42 of 45 


\begin{tabular}{|c|c|c|c|c|}
\hline & $\begin{array}{l}\text { University of } \\
\text { Melbourne }\end{array}$ & & & \\
\hline $\begin{array}{l}\text { Rosie } \\
\text { Watson }\end{array}$ & $\begin{array}{l}\text { Population Health } \\
\text { and Immunity } \\
\text { Division, The Walter } \\
\text { and Eliza Hall } \\
\text { Institute of Medical } \\
\text { Research, Parkville, } \\
\text { Australia }\end{array}$ & A/Prof & PhD & $\begin{array}{l}\text { watson.r@ } \\
\text { wehi.edu.a } \\
\text { u }\end{array}$ \\
\hline $\begin{array}{l}\text { Nawaf } \\
\text { Yassi }\end{array}$ & $\begin{array}{l}\text { Departments of } \\
\text { Medicine and } \\
\text { Neurology, } \\
\text { Melbourne Brain } \\
\text { Centre at the Royal } \\
\text { Melbourne Hospital, } \\
\text { University of } \\
\text { Melbourne, Parkville, } \\
\text { Australia } \\
\\
\text { Population Health } \\
\text { and Immunity } \\
\text { Division, The Walter } \\
\text { and Eliza Hall } \\
\text { Institute of Medical } \\
\text { Research, Parkville, } \\
\text { Australia }\end{array}$ & A/Prof & PhD & $\begin{array}{l}\text { Yassi.n@ } \\
\text { wehi.edu.a } \\
\text { u }\end{array}$ \\
\hline $\begin{array}{l}\text { Cath } \\
\text { Kaylor- } \\
\text { Hughes }\end{array}$ & $\begin{array}{l}\text { Integrated Mental } \\
\text { Health Team } \\
\text { Dept of General } \\
\text { Practice } \\
\text { University of } \\
\text { Melbourne, } 780 \\
\text { Elizabeth St, } \\
\text { Melbourne, } 3010\end{array}$ & Dr. & DPhil & $\begin{array}{l}\text { cath.kaylor } \\
\text { hughes@u } \\
\text { nimelb.edu } \\
\text {.au }\end{array}$ \\
\hline $\begin{array}{l}\text { Richard } \\
\text { Kanaan }\end{array}$ & $\begin{array}{l}\text { Dept of Psychiatry, } \\
\text { University of } \\
\text { Melbourne, Austin } \\
\text { Health, Heidelberg, } \\
\text { VIC } 3084\end{array}$ & Prof. & MBBS, PhD & $\begin{array}{l}\text { richard.kan } \\
\text { aan@unim } \\
\text { elb.edu.au }\end{array}$ \\
\hline $\begin{array}{l}\text { Piero } \\
\text { Perucca }\end{array}$ & $\begin{array}{l}\text { Department of } \\
\text { Medicine, Austin } \\
\text { Health, The } \\
\text { University of } \\
\text { Melbourne; } \\
\text { Comprehensive } \\
\text { Epilepsy Program, } \\
\text { Austin Health; } \\
\text { Department of } \\
\text { Neuroscience, } \\
\text { Central Clinical } \\
\text { School, Monash } \\
\text { University; } \\
\text { Department of } \\
\text { Neurology, The } \\
\text { Royal Melbourne } \\
\text { Hospital; Department } \\
\text { of Neurology, Alfred } \\
\text { Health, Melbourne, } \\
\text { VIC, Australia }\end{array}$ & A/Prof & $\begin{array}{l}\text { MD, PhD, } \\
\text { FRACP }\end{array}$ & $\begin{array}{l}\text { piero.peru } \\
\text { cca@unim } \\
\text { elb.edu.au }\end{array}$ \\
\hline
\end{tabular}




\begin{tabular}{|c|c|c|c|c|}
\hline $\begin{array}{l}\text { Lucy } \\
\text { Vivash }\end{array}$ & $\begin{array}{l}\text { The Department of } \\
\text { Neuroscience, The } \\
\text { Central Clinical } \\
\text { School, The Alfred } \\
\text { Hospital, Monash } \\
\text { University; and The } \\
\text { Departments of } \\
\text { Medicine and } \\
\text { Neurology, The } \\
\text { Royal Melbourne } \\
\text { Hospital, The } \\
\text { University of } \\
\text { Melbourne, Victoria, } \\
\text { Australia }\end{array}$ & $\mathrm{Dr}$ & MSci, PhD & $\begin{array}{l}\text { lucy.vivash } \\
\text { @monash. } \\
\text { edu }\end{array}$ \\
\hline $\begin{array}{l}\text { Rashida } \\
\text { Ali }\end{array}$ & $\begin{array}{l}\text { Alfred Health; } \\
\text { Monash University }\end{array}$ & Ms & MSc & $\begin{array}{l}\text { rashida.ali } \\
\text { @monash. } \\
\text { edu }\end{array}$ \\
\hline $\begin{array}{l}\text { Terence } \\
\text { J. O'Brien }\end{array}$ & $\begin{array}{l}\text { The Department of } \\
\text { Neuroscience, The } \\
\text { Central Clinical } \\
\text { School, The Alfred } \\
\text { Hospital, Monash } \\
\text { University; and The } \\
\text { Departments of } \\
\text { Medicine and } \\
\text { Neurology, The } \\
\text { Royal Melbourne } \\
\text { Hospital, The } \\
\text { University of } \\
\text { Melbourne, Victoria, } \\
\text { Australia }\end{array}$ & Prof. & MD, FRACP & $\begin{array}{l}\text { terence.ob } \\
\text { rien@mon } \\
\text { ash.edu }\end{array}$ \\
\hline $\begin{array}{l}\text { Colin L } \\
\text { Masters }\end{array}$ & $\begin{array}{l}\text { National Dementia } \\
\text { Diagnostics } \\
\text { Laboratory, The } \\
\text { Florey Institute, } \\
\text { University of } \\
\text { Melbourne }\end{array}$ & & $\mathrm{MD}$ & $\begin{array}{l}\text { c.masters } \\
\text { @unimelb. } \\
\text { edu.au }\end{array}$ \\
\hline $\begin{array}{l}\text { Steven } \\
\text { Collins }\end{array}$ & $\begin{array}{l}\text { Australian National } \\
\text { Creutzfeldt-Jakob } \\
\text { Disease Registry, } \\
\text { Florey Institute of } \\
\text { Neuroscience and } \\
\text { Mental Health and } \\
\text { Department of } \\
\text { Medicine, The } \\
\text { University of } \\
\text { Melbourne. }\end{array}$ & Professor & $\mathrm{MD}$ & $\begin{array}{l}\text { s.collins@ } \\
\text { unimelb.ed } \\
\text { u.au }\end{array}$ \\
\hline $\begin{array}{l}\text { Wendy } \\
\text { Kelso }\end{array}$ & $\begin{array}{l}\text { Neuropsychiatry, } \\
\text { Royal Melbourne } \\
\text { Hospital }\end{array}$ & $\mathrm{Dr}$ & & $\begin{array}{l}\text { Wendy.Kel } \\
\text { so@mh.or } \\
\text { g.au }\end{array}$ \\
\hline $\begin{array}{l}\text { Andrew } \\
\text { Evans }\end{array}$ & $\begin{array}{l}\text { Neuropsychiatry, } \\
\text { Royal Melbourne } \\
\text { Hospital }\end{array}$ & A/Prof & & $\begin{array}{l}\text { Andrew.Ev } \\
\text { ans@mh.o } \\
\text { rg.au }\end{array}$ \\
\hline $\begin{array}{l}\text { Anna } \\
\text { King }\end{array}$ & $\begin{array}{l}\text { The Wicking } \\
\text { Dementia Centre, } \\
\text { Tasmania }\end{array}$ & Professor & & $\begin{array}{l}\text { a.e.king@ } \\
\text { utas.edu.a } \\
\text { u }\end{array}$ \\
\hline $\begin{array}{l}\text { Patrick } \\
\text { Kwan }\end{array}$ & $\begin{array}{l}\text { Alfred Hospital; } \\
\text { Monash University, } \\
\text { Melbourne }\end{array}$ & Professor & & $\begin{array}{l}\text { patrick.kw } \\
\text { an@mona } \\
\text { sh.edu }\end{array}$ \\
\hline
\end{tabular}

Page 44 of 45 


\begin{tabular}{|c|c|c|c|}
\hline $\begin{array}{l}\text { Jane } \\
\text { Gunn }\end{array}$ & $\begin{array}{l}\text { Department of } \\
\text { General Practice, } \\
\text { The University of } \\
\text { Melbourne }\end{array}$ & Professor & $\begin{array}{l}\text { j.gunn@un } \\
\text { imelb.edu. } \\
\text { au }\end{array}$ \\
\hline $\begin{array}{l}\text { Ilias } \\
\text { Goranitis }\end{array}$ & $\begin{array}{l}\text { Health Economics } \\
\text { Unit | Centre for } \\
\text { Health Policy | } \\
\text { Melbourne School of } \\
\text { Population and } \\
\text { Global Health, The } \\
\text { University of } \\
\text { Melbourne }\end{array}$ & $\mathrm{Dr}$ & $\begin{array}{l}\text { ilias.gorani } \\
\text { tis@unime } \\
\text { lb.edu.au }\end{array}$ \\
\hline
\end{tabular}

